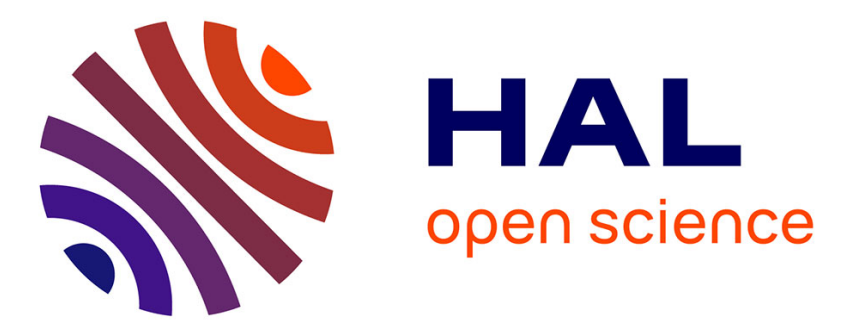

\title{
How Sensitive are Optimal Fully Renewable Power Systems to Technology Cost Uncertainty?
}

Behrang Shirizadeh, Quentin Perrier, Philippe Quirion

\section{To cite this version:}

Behrang Shirizadeh, Quentin Perrier, Philippe Quirion. How Sensitive are Optimal Fully Renewable Power Systems to Technology Cost Uncertainty?. Energy Journal, 2022, 43 (1), 10.5547/01956574.43.1.bshi . hal-03100326

\section{HAL Id: hal-03100326 \\ https://hal.science/hal-03100326}

Submitted on 21 Dec 2021

HAL is a multi-disciplinary open access archive for the deposit and dissemination of scientific research documents, whether they are published or not. The documents may come from teaching and research institutions in France or abroad, or from public or private research centers.
L'archive ouverte pluridisciplinaire HAL, est destinée au dépôt et à la diffusion de documents scientifiques de niveau recherche, publiés ou non, émanant des établissements d'enseignement et de recherche français ou étrangers, des laboratoires publics ou privés. 


\title{
How sensitive are optimal fully renewable power systems to technology cost uncertainty?
}

\author{
Behrang Shirizadeh $^{\mathrm{a}, \mathrm{b}} *$, Quentin Perrier ${ }^{\mathrm{c}}$ and Philippe Quirion ${ }^{\mathrm{a}}$
}

\begin{abstract}
Many studies have demonstrated the feasibility of fully renewable power systems. Yet the future costs of key technologies are highly uncertain, and little is known about the robustness of a renewable power system to these uncertainties. To analyze it, we build 315 cost scenarios by varying the costs of key technologies and we model the optimal renewable power system for France, simultaneously optimizing investment and dispatch. We add to the literature by studying a consecutive 18-years weather period; by testing all combinations of technology costs rather than changing them one-at-a-time; and by calculating the regret from optimizing the energy mix on the basis of cost assumptions that do not materialize.

Our results indicate that the cost of a $100 \%$ system is not that sensitive to uncertainty. Admittedly, the optimal energy mix is highly sensitive to cost assumptions: across our scenarios, the installed capacity in PV, onshore wind and power-to-gas varies by a factor of 5 , batteries and offshore wind even more. However, in every scenario the total production and storage cost is similar to, or lower than the current cost. This indicates that renewable technologies will become by and large substitutable. Moreover, even if the energy mix is optimized based on cost assumptions which turn out to be wrong, the extra cost is low: $4 \%$ in average and less than $9 \%$ in $95 \%$ of the scenarios.
\end{abstract}

Keywords: Power system modelling; Variable renewables; Electricity storage; Robust decision making.

JEL classification: C21; O21; Q21; Q47; Q48.

\footnotetext{
${ }^{\text {a }}$ CIRED-CNRS, 45 bis avenue de La Belle Gabrielle, 94736 Nogent sur Marne Cedex, France

${ }^{\mathrm{b}}$ TOTAL, GRP, R\&D group, 2 place Jean Millier, 92078 Paris la Défense Cedex, France.

${ }^{c}$ CIRED-CNRS, 45 bis avenue de La Belle Gabrielle, 94736 Nogent sur Marne Cedex, France

* Corresponding author: shirizadeh@centre-cired.fr, +33 (0)1 43947478
} 


\section{Introduction $^{1}$}

According to Article 4.1 of the Paris Agreement, the Parties shall endeavor to rapidly reduce greenhouse gas emissions in order to achieve a balance between anthropogenic emissions by sources and removals by sinks in the second half of this century. The electricity sector will have a key role to play, as decarbonisation is easier in this sector than in transport, buildings or agriculture. Renewable energy will be the cornerstone of decarbonisation, making a greater contribution than nuclear energy and fossil fuels with $\mathrm{CO}_{2}$ capture and storage (Rogelj et al., 2018).

While the feasibility of a $100 \%$ renewable electricity system has already been highlighted by many studies (Brown et al, 2018, and references therein), the cost of such a system is heavily debated. Following Joskow (2011), Hirth (2015) and Hirth et al. (2016), many articles have focused on the optimal proportion of renewable energies in the electricity mix. This literature has highlighted the existence of systemic integration costs related to the deployment of variable renewable energies. In particular, a "self-cannibalization" phenomenon was highlighted, linked to the fact that all the solar panels or wind turbines in a given location produce their electricity at the same time. In the absence of affordable storage, these integration costs have two consequences: (i) deployment of renewable energies leads to a significant additional cost, rapidly increasing with the deployment rate; (ii) the right balance must be struck between the different production technologies to minimize this additional cost.

However, these results of increasing costs and right balance might not hold much longer, due to the rapid decline in storage costs and the fact that recent wind turbines benefit from a flatter production profile than older models (Hirth and Müller, 2016).

If this phenomenon of increasing costs does not hold any more, it means that the relationship between renewable energy sources is changing from being complements to being substitutes. It would be then possible to identify one or several "robust" energy mixes, in the sense that their overall cost does not vary much, even if the cost of the different technologies finally differs from the initial forecast.

To shed light on these questions, we build a new open-source model called EOLES (Energy Optimization for Low Emission Systems) and apply it to continental France. EOLES minimizes the total system cost while satisfying energy demand at each hour for a period of up to 18 years. It includes six power generation technologies (offshore and onshore wind, solar, two types of hydro

\footnotetext{
${ }^{1}$ We thank four anonymous referees from The Energy Journal and an anonymous referee from the FAERE Working papers series for their very useful comments, which have significantly improved the paper.
} 
and biogas) and three storage technologies (batteries, pumped hydro and powerto-gas).

Using this model, we study the sensitivity of the power mix in 2050, through 315 cost scenarios for 2050, varying all key technology costs: onshore and offshore wind by $+/-25 \%$; PV, batteries and power-to-gas by $+/-50 \%$. Most existing studies are based on a single weather-year or on a few ones, and when a sensitivity analysis on technology costs is performed, it generally varies these costs one-at-a-time. We add to this literature by studying a consecutive 18 -years weather period and carefully choosing a representative year for the sensitivity analysis; by testing all combinations of technology costs rather than changing them one-at-a-time; and by calculating the regret from optimizing the energy mix on the basis of cost assumptions that do not materialize.

The remainder of this paper is organized as follows. In Section 2 we present the EOLES_elecRES model, the $100 \%$ renewable electricity sector version of EOLES family of models. Results are presented in Section 3 while Section 4 provides a discussion and concludes.

\section{Materials and methods}

\subsection{Model description}

EOLES_elecRES is a dispatch and investment model that minimizes the annualized power generation and storage costs, including the cost of connection to the grid. It includes six power generation technologies: offshore and onshore wind power, solar photovoltaics (PV), run-of-river and lake-generated hydroelectricity, and biogas combined with open-cycle gas turbines. It also includes three energy storage technologies: pump-hydro storage (PHS), batteries and methanation combined with open-cycle gas turbines. These technologies are shown in Figure 1.

The model considers continental France as a single node. PV and onshore wind are simulated for the 95 counties (départements, an administrative entity corresponding to the European NUTS 3 level). The proportion of the installed capacity in each department remains the same in all simulations, at the level observed in 2017. We consider that this is the best simple method to represent the possible future repartition of these capacities, because it takes into account the local resource (e.g. more PV in the South, more wind in the North), land availability and social acceptability (e.g. little possibility to install wind farms in densely populated areas, in the mountains or in very touristic locations). As detailed in subsection 2.3 below, this scale-up method applies neither to hydro, which is capped by assumption due to the very limited availability of new production sites, nor to offshore wind, for which the repartition of capacities follows the existing offshore projects around France, identified through the " $4 \mathrm{C}$ offshore" website. 
The model is written in GAMS and solved using the CPLEX solver. The code and data are available on GitHub. ${ }^{1}$ EOLES uses only linear optimization. Nonlinear constraints might improve accuracy, in particular when studying unit commitment, but they entail significant increase in computation time. Palmintier (2014) has shown that linear programming provides an interesting trade-off, with little impacts on cost, $\mathrm{CO}_{2}$ emissions and investment estimations, but a speed-up by up to $x 1500$.

Figure 2 provides an illustrative output of the model, i.e. the optimal dispatch for a week in winter and for a week in summer, for each hour of the week.

The remainder of this section presents the main equations (2.2) and the input data (2.3). A detailed description of all sets, parameters and variables of the model is available in Appendix 4.

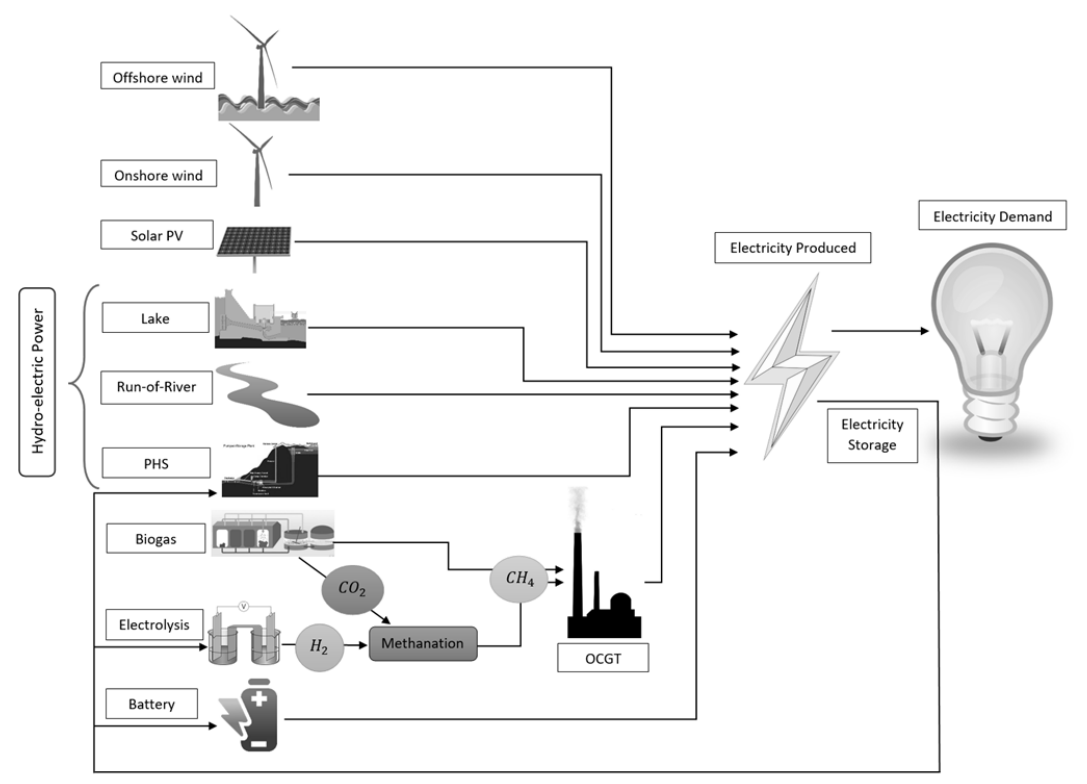

Figure 1 Graphical description of the EOLES_elecRES model

${ }^{1}$ https://github.com/BehrangShirizadeh/EOLES elecRES 


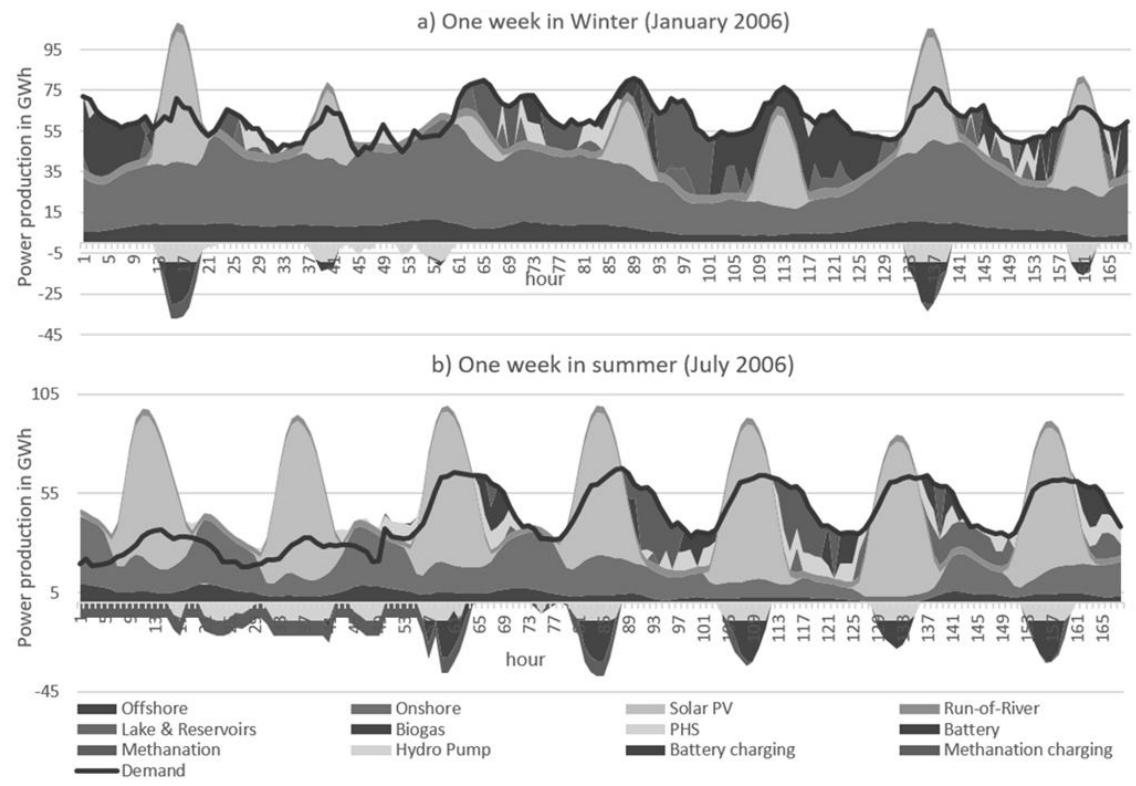

Figure 2 Hourly power generation, electricity demand, storage charge and discharge profiles for (a) the third week of January (Winter) and (b) the third week of July

(Summer) 2006

\subsection{Model equations}

\section{Objective Function}

In EOLES, dispatch and investment are determined simultaneously by linear optimization. CAPEX (capital expenditure) and OPEX (operational expenditure).

The objective function, shown in Equation (1), is the sum of all costs over the chosen period, including fixed investment costs, fixed O\&M costs (which are both annualized) and variable costs. For some storage options, in addition to the CAPEX related to charging capacity per $k W_{e}$, another type of CAPEX is introduced: a capex related to energy capacity, per $k W h_{e}$

$$
\begin{gathered}
\operatorname{COST}=\left(\sum_{t e c}\left[\left(Q_{t e c}-q_{t e c}^{e x}\right) \times \text { annuity }_{\text {tec }}\right]+\sum_{\text {str }}\left(V_{O L U M} E_{\text {str }} \times\right.\right. \\
\text { annuitystren })+\operatorname{tec}(Q \text { tec } \times \text { fo\&Mtec })+\operatorname{str}(\text { Sstr } \times \text { capexstrch }+ \text { fo\&Mstrch } \\
) \text { tech }(\text { Gtec, } h \times \text { vo\&Mtec }) / 1000 \text { (1) }
\end{gathered}
$$

where $Q_{t e c}$ represents the installed capacities of production, VOLUME $E_{s t r}$ is the volume of energy storage in MWh, $S_{\text {str }}$ is the capacity of storage in MW, annuity is the annualized investment cost, $f O \& M$ and $v O \& M$ respectively 
represents fixed and variable operation and maintenance costs and $G_{t e c, h}$ is the hourly generation of each technology.

To calculate the annualized capex (annuity tec $_{\text {in }}$ the objective function), we use the following equation:

$$
\text { annuity }_{\text {tec }}=\frac{D R \times C A P E X_{t e c}}{1-(1+D R)^{-l t}}(2)
$$

Where $D R$ is the discount rate.

\section{Adequacy equation}

Electricity demand must be met for each hour. If power production exceeds electricity demand, the excess electricity can be either sent to storage units or curtailed (equation 3 ).

$$
\sum_{t e c} G_{t e c, h} \geq \text { demand }_{h}+\sum_{s t r} S T O R A G E_{\text {str }, h}
$$

Where $G_{t e c, h}$ is the power produced by technology tec at hour $h$ and $S T O R A G E_{s t r, h}$ is the energy entering the storage technology str at hour $h$.

\section{Renewable power production}

For each variable renewable energy (VRE) technology, the hourly power production is given by the hourly capacity factor profile multiplied by the installed capacity available for each hour (equation 4).

$$
G_{\text {vre }, h}=Q_{\text {vre }} \times c f_{\text {vre }, h}
$$

Where $G_{v r e, h}$ is the electricity produced by each VRE resource at hour $h, Q_{v r e}$ is the installed capacity and $c f_{v r e, h}$ is the hourly capacity factor.

\section{Energy storage}

Energy stored by storage option str at hour $h+1$ is equal to the energy stored at hour $h$ plus the difference between the energy entering and leaving the storage option at hour $h$, accounting for charging and discharging efficiencies (equation $5)$ :

$$
S T O R E D_{s t r, h+1}=S T O R E D_{s t r, h}+\left(S T O R A G E_{s t r, h} \times \eta_{s t r}^{\text {in }}\right)-\left(\frac{G_{s t r, h}}{\eta_{s t r}^{\text {out }}}\right)
$$

Where $S T O R E D_{s t r, h}$ is the energy in storage option str at hour $h$, while $\eta_{s t r}^{i n}$ and $\eta_{\text {str }}^{\text {out }}$ are the charging and discharging efficiencies. 


\section{Secondary reserve requirement}

Three types of operating reserves are defined by ENTSO-E (2013), according to their activation speed. The fastest reserves are Frequency Containment Reserves (FCRs), which must be able to be on-line within 30 seconds. The second group is made up of Frequency Restoration Reserves (FRRs), in turn divided into two categories: a fast automatic component (aFRRs), also called 'secondary reserves', with an activation time of no more than $7.5 \mathrm{~min}$; and a slow manual component (mFRRs), or 'tertiary reserves', with an activation time of no more than 15 min. Finally, reserves with a startup-time beyond 15 minutes are classified as Replacement Reserves (RRs).

Each category meets specific system needs. The fast FCRs are useful in the event of a sudden break, like a line fall, to avoid system collapse. FRRs are useful for variations over several minutes, such as a decrease in wind or PV output. Finally, the slow RRs act as a back-up, slowly replacing FCRs or FRRs when the system imbalance lasts more than 15 minutes.

In the model we only consider FRRs, since they are the most impacted by VRE integration. FRRs can be defined either upwards or downwards, but since the electricity output of VREs can be curtailed, we consider only upward reserves.

The quantity of FRRs required to meet ENTSO-E's guidelines is given by equation (6). These FRR requirements vary with the variation observed in the production of renewable energies. They also depend on the observed variability in demand and on forecast errors:

$$
\begin{gathered}
\sum_{f r r} R S V_{f r r, h}=\sum_{\text {vre }}\left(\varepsilon_{\text {vre }} \times Q_{\text {vre }}\right)+\underset{\text { demand }}{h} \times\left(1+\delta_{\text {variation }}^{\text {load }}\right) \times \\
\delta_{\text {uncertainty }}^{\text {load }}
\end{gathered}
$$

Where $R S V_{f r r, h}$ is the required hourly reserve capacity from each of the reserveproviding technologies (dispatchable technologies) indicated by the subscript frr; $\varepsilon_{\text {vre }}$ is the additional FRR requirement for VRE because of forecast errors, $\delta_{\text {variation }}^{\text {load }}$ is the load variation factor and $\delta_{\text {uncertainty }}^{\text {load }}$ is the uncertainty factor in the load because of hourly demand forecast errors. The method for calculating these various coefficients according to ENSTO-E guidelines is detailed by Van Stiphout et al. (2017).

\section{Power-production-related constraints}

The relationship between hourly-generated electricity and installed capacity can be calculated using equation (7). Since the chosen time slice for the optimization is one hour, the capacity enters the equation directly instead of being multiplied by the time slice value.

$$
G_{t e c, h} \leq Q_{t e c}
$$


The installed capacity of all the dispatchable technologies should be more than the electricity generation required of those technologies to meet demand; it should also satisfy the secondary reserve requirements Installed capacity for dispatchable technologies can therefore be expressed by equation (8).

$$
Q_{f r r} \geq G_{f r r, h}+R S V_{f r r, h}(8)
$$

Monthly available energy for the hydroelectricity generated by lakes and reservoirs is defined using monthly lake inflows (equation 9). This means that energy stored can be used within the month but not across months. This is a parsimonious way of representing the non-energy operating constraints faced by dam operators, as in Perrier (2018).

$$
\text { lake }_{m} \geq \sum_{\text {for } h \in m} G_{\text {lake, } h}(9)
$$

Where $G_{\text {lake }, h}$ is the hourly power production by lakes and reservoir, and lake $e_{m}$ is the maximum electricity that can be produced from this energy resource during one month. This parameter is calculated by summing hourly power production from this hydroelectric energy resource over each month of the year to capture the meteorological variation of hydroelectricity, using the online portal of $\mathrm{RTE}^{1}$ (the French transmission network operator).

The energy that can be produced by biogas is limited, since the main resources of this energy are methanization (anaerobic digestion) and pyro-gasification of solid biomass. Both processes are limited by several constraints and according to ADEME (2013) electricity from biogas produced by these two processes can be projected as $15 \mathrm{TWh}$ per year from 2030 on $\left(e_{\text {biogas }}^{\max }\right)$, which is presented in equation 10.

$$
\sum_{h=0}^{8759} G_{\text {biogas }, h} \leq e_{\text {biogas }}^{\max }(10)
$$

Run-of-river power plants represent another source of hydro-electricity power. River flow is also strongly dependent on meteorological conditions and it can be considered as a variable renewable energy resource. Hourly run-of-river power production data from the RTE online portal has been used to prepare the hourly capacity factor profile of this energy resource, river $_{h}$ in equation (11);

$$
G_{\text {river }, h}=Q_{\text {river }} \times \text { river }_{h}
$$

As shown in Figure 1, two renewable gas technologies are considered; biogas and methanation. Both of them produce renewable methane, which can be used in gas power plants. In the model, the latter is considered to be an open cycle gas

\footnotetext{
${ }^{1}$ https://www.rte-france.com/fr/eco2mix/eco2mix-telechargement
} 
turbine (OCGT) due to its high operational flexibility and equation (12) shows the relationship of the power production from these two methane resources;

$$
G_{g a s, h}=\sum_{c o m b} G_{c o m b, h} \quad(12)
$$

Where $G_{c o m b, h}$ is the power production from each renewable gas resource, and $G_{g a s, h}$ is the power production from the OCGT power plant which uses these two resources as fuel. It is worth mentioning that the efficiency of this combustion process is considered in both the $15 T W h_{e}$ of annual electricity production from biogas, and the discharge efficiency of the methanation process as defined in equation (5).

The maximum installed capacity of each technology depends on land-userelated constraints, social acceptance, the maximum available natural resources and other technical constraints; therefore, a technological constraint on maximum installed capacity is defined in equation (13) where $q_{t e c}^{\max }$ is this capacity limit, taken from the development trajectories for the French electricity mix for the period 2020-2060 (ADEME, 2018):

$$
Q_{t e c} \leq q_{t e c}^{\max }
$$

\section{Storage-related constraints}

To prevent optimization leading to a very high amount of stored energy in the first hour represented and a low one in the last hour, we add a constraint to ensure the replacement of the consumed stored electricity in every storage option (equation 14):

$$
S T O R E D_{s t r, h=0} \leq S T O R E D_{s t r, h=8759}
$$

While equations (5) and (14) define the storage mechanism and constraint in terms of power, we also limit the available volume of energy that can be stored by each storage option (equation 15):

$$
\text { STORED } D_{\text {str }, h} \leq \text { VOLUME } E_{\text {str }}
$$

Equation (16) limits the energy entry to the storage units to the charging capacity of each storage unit, which means that the charging capacity cannot exceed the discharging capacity.

$$
\text { STORED } D_{\text {str }, h} \leq S_{\text {str }} \leq Q_{\text {str }}
$$




\subsection{Input data}

Input data can be placed in three main classes: cost data, VRE profiles and electricity demand profiles.

\section{Cost data}

The economic parameters for generation technologies are taken from JRC (2014, 2017) and summarized in Table 1. It is worth mentioning that the grid upgrading cost of $€ 24.6 / \mathrm{kW}$ for new renewable power plants mandated by the transport system operator RTE and by the distribution system operator ENEDIS (RTE, 2018b) has been added to the capital expenditure values of each VRE technology. The annuities (annualized CAPEX) are the results of these calculations. More information about the cost scenarios and the estimation methodology used in JRC (2017) can be found in Appendix 1.

Table 1 Economic parameters of power production technologies

\begin{tabular}{|c|c|c|c|c|c|c|}
\hline Technology & $\begin{array}{l}\text { CAPEX } \\
\left(€ / \mathbf{k} W_{\mathrm{e}}\right)\end{array}$ & $\begin{array}{l}\text { Lifetime } \\
\text { (years) }\end{array}$ & $\begin{array}{c}\text { Annuity } \\
\left(€ / \mathbf{k} \mathbf{W}_{\mathrm{e}} / \text { year }\right)\end{array}$ & $\begin{array}{l}\text { Fixed O\&M } \\
\left(€ / \mathbf{k} W_{\mathrm{e}} / \text { year }\right)\end{array}$ & $\begin{array}{c}\text { Variable } \\
\text { O\&M } \\
\left(€ / \mathbf{M W h}_{\mathrm{e}}\right)\end{array}$ & Source \\
\hline $\begin{array}{l}\text { Offshore wind } \\
\text { farm }^{*}\end{array}$ & 2330 & 30 & 144.3677 & 47.0318 & 0 & $\begin{array}{l}\text { JRC } \\
(2017)\end{array}$ \\
\hline $\begin{array}{l}\text { Onshore wind } \\
\text { farm }^{*}\end{array}$ & 1130 & 25 & 77.6621 & 34.5477 & 0 & $\begin{array}{l}\text { JRC } \\
(2017)\end{array}$ \\
\hline Solar PV* & 425 & 25 & 30.0052 & 9.2262 & 0 & $\begin{array}{l}\text { JRC } \\
(2017)\end{array}$ \\
\hline $\begin{array}{l}\text { Hydroelectricity } \\
- \\
\text { lake and } \\
\text { reservoir }\end{array}$ & 2275 & 60 & 110.2334 & 11.375 & 0 & $\begin{array}{l}\text { JRC } \\
(2017)\end{array}$ \\
\hline $\begin{array}{l}\text { Hydroelectricity } \\
- \\
\text { run-of-river }\end{array}$ & 2970 & 60 & 143.9091 & 14.85 & 0 & $\begin{array}{l}\text { JRC } \\
(2017)\end{array}$ \\
\hline $\begin{array}{l}\text { Biogas } \\
\text { (Anaerobic } \\
\text { digestion) }\end{array}$ & 2510 & 25 & 135.5066 & 83.9 & 3.1 & $\begin{array}{l}\text { JRC } \\
(2017)\end{array}$ \\
\hline$O C G T$ & 550 & 30 & 33.7653 & 16.5 & 0 & $\begin{array}{l}\text { JRC } \\
(2014)\end{array}$ \\
\hline
\end{tabular}

*For offshore wind power on monopiles at $30 \mathrm{~km}$ to $60 \mathrm{~km}$ from the shore, for onshore wind power, turbines with medium specific capacity $\left(0.3 \mathrm{~kW} / \mathrm{m}^{2}\right)$ and medium hub height $(100 \mathrm{~m})$ and for solar power, an average of the costs of utility scale, commercial scale and residential scale systems without tracking are taken into account. In this cost allocation, we consider solar power as a simple average of ground-mounted, rooftop residential and rooftop commercial technologies. For lake and reservoir hydro we take the mean value of low-cost and high-cost power plants.

For the storage technologies, the "Commercialization of Energy Storage in Europe" report prepared by FCH-JU (2015) and a recent article by Schmidt et al. (2019) about long-term cost projections of storage technologies have been used respectively for pumped hydro storage and Li-Ion battery storage options. "The potential of Power-to-Gas" study by ENEA consulting (2016) has been used for methanation storage. Using these three studies the 2050 cost projection of 
storage technologies are presented in Table 2. The cost of methanation is made up of the cost of electrolysis units and the Sabatier reaction ${ }^{1}$.

Table 2 Economic parameters of storage technologies

\begin{tabular}{|c|c|c|c|c|c|c|c|c|c|}
\hline $\begin{array}{l}\text { Techno } \\
\text { logy }\end{array}$ & $\begin{array}{c}\text { Over } \\
\text { night } \\
\text { costs } \\
(€ / \mathbf{k W} \\
\text { e) }\end{array}$ & $\begin{array}{c}\text { CAP } \\
\mathbf{E X} \\
(€ / \mathbf{k} \\
\left.\mathbf{W h}_{\mathrm{e}}\right)\end{array}$ & $\begin{array}{l}\text { Lifet } \\
\text { ime } \\
\text { (year } \\
\text { s) }\end{array}$ & $\begin{array}{c}\text { Annuit } \\
\mathbf{y} \\
\left(€ / \mathbf{k} W_{\mathrm{e}} /\right. \\
\text { year) }\end{array}$ & $\begin{array}{c}\text { Fixed } \\
\text { O\&M } \\
\left(€ / k W_{\mathrm{e}} /\right. \\
\text { year) }\end{array}$ & $\begin{array}{c}\text { Varia } \\
\text { ble } \\
\text { O\&M } \\
(€ / M \\
\left.W_{h}\right)\end{array}$ & $\begin{array}{c}\text { Storage } \\
\text { annuity } \\
\text { (€/kWhe } \\
\text { /year) }\end{array}$ & $\begin{array}{c}\text { Effici } \\
\text { ency } \\
\text { (input } \\
/ \\
\text { outpu } \\
\text { t) }\end{array}$ & $\begin{array}{c}\text { Sour } \\
\text { ce }\end{array}$ \\
\hline $\begin{array}{l}\text { Pumpe } \\
\text { d hydro } \\
\text { storage } \\
\text { (PHS) }\end{array}$ & 500 & 5 & 55 & 25.8050 & 7.5 & 0 & 0.2469 & $\begin{array}{c}95 \% / 9 \\
0 \%\end{array}$ & $\begin{array}{c}\mathrm{FCH} \\
-\mathrm{JU} \\
(201 \\
5)\end{array}$ \\
\hline $\begin{array}{l}\text { Battery } \\
\text { storage } \\
\text { (Li- } \\
\text { Ion) }\end{array}$ & 140 & 100 & 12.5 & 15.2225 & 1.96 & 0 & 10.6340 & $\begin{array}{c}90 \% / 9 \\
5 \%\end{array}$ & $\begin{array}{l}\text { Sch } \\
\text { midt } \\
(201 \\
9)\end{array}$ \\
\hline $\begin{array}{l}\text { Methan } \\
\text { ation }\end{array}$ & 1150 & 0 & $\begin{array}{c}20 / 2 \\
5 *\end{array}$ & 87.9481 & 59.25 & 5.44 & 0 & $\begin{array}{c}59 \% / 4 \\
5 \%\end{array}$ & $\begin{array}{c}\text { ENE } \\
\text { A } \\
(201 \\
6)\end{array}$ \\
\hline
\end{tabular}

*The lifetime of electrolysis units is 20 years, while the lifetime of methanation units is 25 years.

The carbon dioxide required for methanation is assumed to come from capturing and transporting the excess carbon dioxide resulting from the methanization process (for the production of biogas). About $30 \%$ of the product of bio-methane production from methanization by anaerobic digestion is gas phase carbon dioxide (Ericsson, 2017). According to ZEP (2011), the cost of transporting carbon dioxide along a $200 \mathrm{~km}$ onshore pipeline is €4/tCO .

Considering a $100 \mathrm{~km}$ long onshore pipeline (considering maximum $100 \mathrm{~km}$ of distance between the methanation units and the biogas production units), the $\mathrm{CO}_{2}$ transport cost for the methanation storage is $€ 1 / \mathrm{MWh}$ (See appendix 5), to be added to the gas storage cost which is $€ 2 / \mathrm{MWh}$ (according to the French energy regulation commission (CRE, 2018), the variable cost of the methanation storage is $€ 3 / M W h_{e}$.

\section{VRE profiles}

Variable renewable energies' (offshore and onshore wind and solar PV) hourly capacity factors have been prepared using the renewables.ninja website ${ }^{2}$, which provides the hourly capacity factor profiles of solar and wind power from 2000

\footnotetext{
${ }^{1}$ The reaction that produces methane from hydrogen and carbon dioxide is called the Sabatier reaction.

${ }^{2}$ https://www.renewables.ninja/
} 
to 2017 at the geographical scale of French counties (départements), following the methods elaborated by Pfenninger and Staffell (2016) and Staffell and Pfenninger (2016). These renewables.ninja factors reconstructed from weather data provide a good approximation of observed data: Moraes et al. (2018) finds a correlation of 0.98 for wind and 0.97 for solar power with the in-situ observations provided by the French transmission system operator (RTE).

To prepare hourly capacity factor profiles for offshore wind power, we first identified all the existing offshore projects around France using the " $4 \mathrm{C}$ offshore" website ${ }^{1}$, and using their locations, we extracted the hourly capacity factor profiles of both floating and grounded offshore wind farms. The Siemens SWT 4.0 130 has been chosen as the offshore wind turbine technology because of recent increase in the market share of this model and its high performance. The hub height of this turbine is set to 120 meters.

Appendix 2 provides more information about the methodology used in the preparation of hourly capacity factor profiles of wind and solar power resources.

\section{Electricity demand profile}

Hourly electricity demand is ADEME (2015)'s central demand scenario for 2050. This demand profile falls in the middle of the four proposed demand scenarios for 2050 in France by Arditi et al. (2013) during the national debates on the French energy transition (DNTE). It amounts to $422 T W h_{e} /$ year, $12 \%$ less than the average power consumption in the last 10 years. We include this demand profile rather than the one observed in recent years because by 2050 , electricity demand will have been impacted by climate change, progress in energy efficiency and new uses of electricity.

\section{Discount rate}

We use a discount rate of $4.5 \%$ i.e. the value recommended by the French government for use in public socio-economic analyses (Quinet, 2014).

\subsection{Cost scenarios}

To test the sensitivity of the optimal power to the costs of various technologies, we consider the range of uncertainty indicated in Table 3. For power generation technologies, uncertainty applies to the fixed costs, defined as capital costs and fixed operation and maintenance costs. For storage technologies, it applies to the main cost component of each of them; fixed costs for methanation (similar to power generation technologies) and energy-related CAPEX for batteries.

\footnotetext{
${ }^{1}$ https://www.4coffshore.com/
} 
For solar PV, the +/- 50\% uncertainty range is chosen to reflect the various scenarios in the JRC (2017) study. We chose the same +/- 50\% uncertainty range for batteries, the lower bound being based on the prolongation of the assessment made by BNEF (2017) for 2030, and the upper bound being chosen to keep symmetry in the uncertainty ranges. For methanation, less information is available in the literature. We also chose a $+/-50 \%$ uncertainty range since we consider that it has reached a similar maturity stage as batteries. Moreover, the upper bound is close to the 2030 projection of ENEA consulting (2016). For wind technologies (a more mature technology), the choice of a $+/-25 \%$ uncertainty range comes from the expert elicitation survey by Wiser et al. (2016).

No variation in the cost of hydro and biogas is accounted for, the former because it is a mature technology with low uncertainty and the latter because in the model the amount of biogas used is determined by the availability constraint, not by its cost.

Table 3 Variations in the costs of key technologies accounted for in the sensitivity analysis

\begin{tabular}{|l|c|c|c|c|c|}
\hline Technology & Solar PV & $\begin{array}{l}\text { Offshore } \\
\text { wind }\end{array}$ & $\begin{array}{l}\text { Onshore } \\
\text { wind }\end{array}$ & Batteries & Methanation \\
\hline $\begin{array}{l}\text { Uncertainty } \\
\text { range }\end{array}$ & $\begin{array}{c}-50 \% ;-25 \% ; \\
0 \% ;+25 \% ; \\
+50 \%\end{array}$ & $\begin{array}{c}-25 \% ; 0 \% ; \\
+25 \%\end{array}$ & $\begin{array}{c}-25 \% ; 0 \% ; \\
+25 \%\end{array}$ & $\begin{array}{c}-50 \% ; 0 \% ; \\
+50 \%\end{array}$ & $\begin{array}{c}-50 \% ; 0 \% ; \\
+50 \%\end{array}$ \\
\hline
\end{tabular}

All the combinations of variations presented in Table 3 would give 405 different cost scenarios $\left(5^{1} \times 3^{4}\right)$. Out of all these options, we select 315 scenarios which provide higher internal consistency. Indeed, a future in which offshore wind would be more expensive than expected and onshore wind cheaper than expected (or vice-versa) is not realistic, so we select only the scenarios in which the costs of these technologies can only differ by $25 \%$ at most. This leads to seven different offshore and onshore wind power cost scenario combinations. Multiplying by five solar power cost scenarios and three cost scenarios for each storage technology $\left(7 \times 5^{1} \times 3^{2}\right)$, we obtain 315 future cost scenarios.

Optimizing the model for every 315 cost scenario over 18 years would have been impossible for computational reasons. Therefore, we first ran the annual model over each weather-year from 2000 to 2017, we chose a representative weather-year (2006), then we performed the sensitivity analysis over this representative weather-year. 


\section{Results}

\subsection{Weather-year selection}

\section{Testing sensitivity to the choice of a weather-year}

To test how the optimal mix of variable renewables varies for different weatheryears, we ran the model for each year from 2000 to 2017 (henceforth "weatheryears").

Our results show that the optimal power mix varies significantly from one year to another, in terms of electricity production, installed capacity, storage volume and storage capacity (Figures 3 and 4 and Appendix 3). The largest variations between minimum and maximum installed capacity are associated with onshore and offshore wind power. In particular, offshore capacity ranges from zero to 20 $\mathrm{GW}$, which is the maximum value allowed ${ }^{1}$. High values for offshore wind are reached either for weather-years with a high capacity factor for offshore wind (as in 2015) or for weather-years with a low capacity factor for onshore wind (as in 2016). In comparison, installed solar capacity is more stable (between $100.5 \mathrm{GW}$ and $122.2 \mathrm{GW}$ ), due to a less volatile capacity factor (Figure $4 \mathrm{c}$ ). Biogas always reaches the maximum allowed power generation and hydro the maximum allowed capacity. As far as storage capacity is concerned, pumped hydro storage (PHS) also always reaches its maximum value while batteries and methanation vary a lot across weather-years (Figures $4 \mathrm{~d} 1$ and $4 \mathrm{~d} 2$ ). In comparison, the system-wide LCOE and average power price (the dual variable of the adequacy constraint, i.e. equation 3), as well as the sum of VRE curtailment and storage losses are much more stable (Figures $4 \mathrm{e}$ and $4 \mathrm{f}$ ).

\footnotetext{
${ }^{1}$ Maximum values are not binding for solar PV and onshore wind.
} 


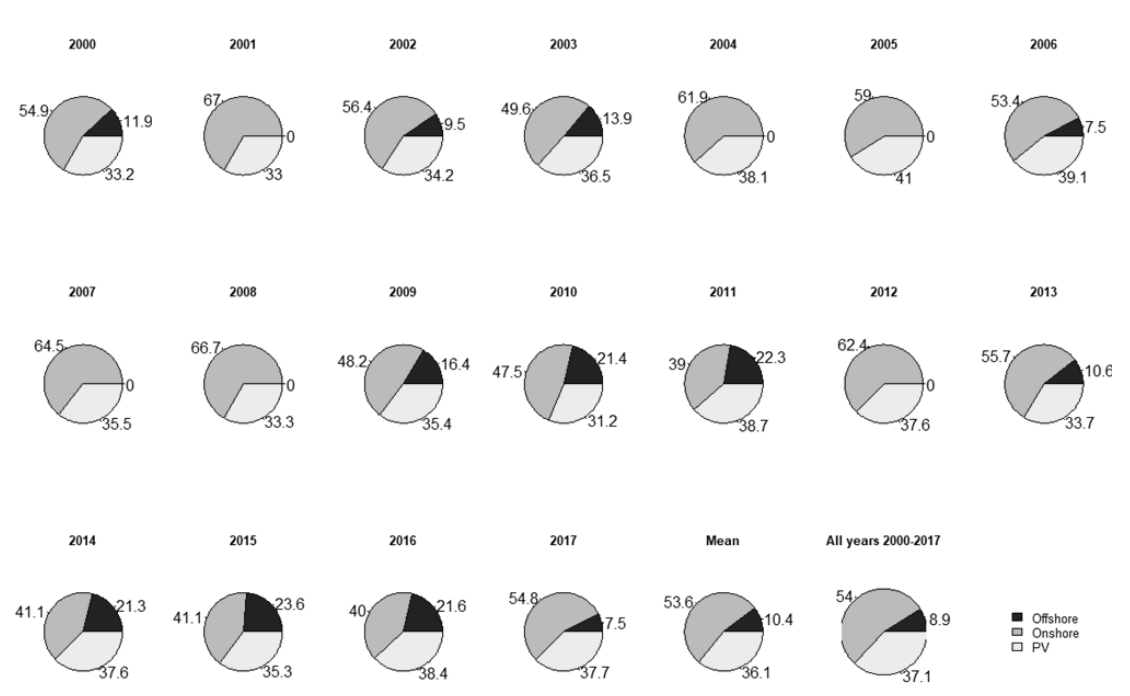

Figure 3 VRE generation mix for each weather-year in single-year optimization and over the whole 18-year long period

These results show that if the aim is to find an optimal energy mix, running a model on a randomly-chosen weather-year can be very misleading. The optimal mix of renewables is highly sensitive to the chosen weather-year. This conclusion is consistent with those of Collins et al. (2018) and Zeyringer et al. (2018). Therefore, the best approach would be to run the model over several weather-years, as in our 18-year simulation.

However, the drawback is a much longer optimization time, which prevents us from doing this for the 315 cost scenarios used in our sensitivity analysis. Hence, we have chosen another approach: selecting a representative year that gives the results closest to the results when optimizing over 18 years.

\section{Selecting a representative weather-year}

The selection of a representative year could be made using several criteria. We chose to select the year with a capacity factor closest to our 18-year optimal mix. We used the capacity factor because it is invariable with respect to technology costs, on which we perform the sensitivity analysis. To measure the distance to the 18-year optimal mix, we computed the sum of absolute difference $^{1}$ of the three VREs. We also calculated the mean squared error $^{2}$ which

\footnotetext{
${ }^{1}$ Sum of normalized absolute differences $\sum_{i=1}^{3}\left|\frac{x_{i}-x^{*}}{x^{*}{ }_{i}}\right|$ where $x_{i}$ is the average capacity factor (CF) of each technology $i$ in each year and $x^{*}{ }_{i}$ is the average CF of that technology over 18 years.

${ }^{2}$ Sum of the squared differences $\frac{1}{3} \sum_{i=1}^{3}\left(x_{i}-x_{i}^{*}\right)^{2}$ where $x_{i}$ is the average capacity factor (CF) of each technology $i$ in each year and $x^{*}{ }_{i}$ is the average $\mathrm{CF}$ of that technology over 18 years.
} 
puts more weight on outliers. Using both approaches, 2006 is the closest year to the overall 18-year long period, with a sum of absolute error values of $1.5 \%$ (Table 4 in Appendix 3).

We launched the model with the optimal installed capacities found for 2006 over all other weather-years to test the adequacy of this installed capacity with respect to the other 17 weather-years, and we did not observe any operational inadequacy.
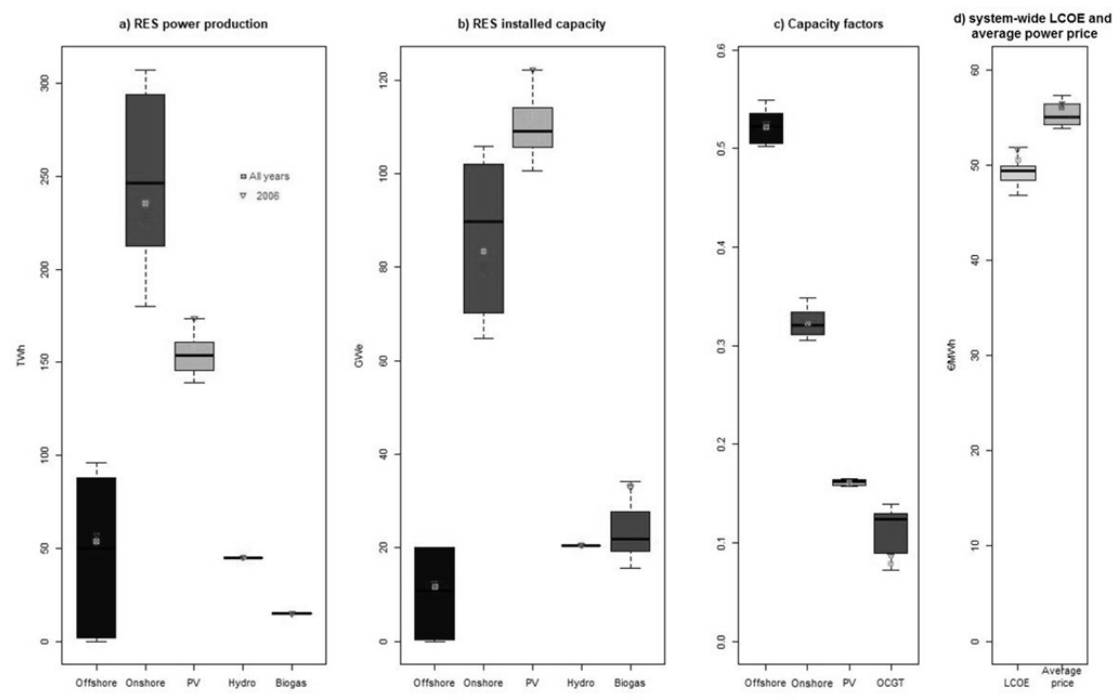

Figure 4. Optimization results for each weather-year from 2000 to 2017 and for the whole 18-year period. (a) power production; (b) installed capacity; (c) average capacity factor of each VRE and the gas power plant for biogas produced by anaerobic digestion and methane produced by methanation and $(d)$ system-wide LCOE and average power price of electricity. The square-shaped light marks show the results of the optimization over the 18-year period and the triangle-shaped dark ones show the results for weatheryear 2006. The box plots show the first and third quartiles and the median for each scenario.

Figure 5 shows the energy mix of the chosen representative year (2006) and the whole 18-year modelling. There is a very close match between the percentage of each energy source for the overall 18-year-long optimization and the representative year. Onshore wind power is clearly dominant with solar power and offshore wind power as the second- and third- biggest sources of energy respectively. 

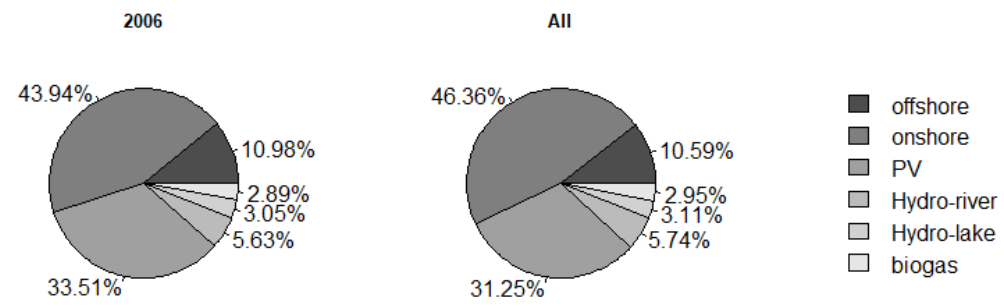

Figure 5: Energy mix for the chosen representative weather-year (2006, left) and for the 18-year optimization (right)

\subsection{The optimal power mix is highly sensitive to technology cost assumptions}

Our results indicate that the optimal energy mix is highly sensitive to cost uncertainty. Offshore wind often reaches either zero installed capacity or the maximum allowed value, while the range of onshore wind and PV capacities is approximately five-fold across the cost scenarios (Figure 6a). Storage technologies also demonstrate such high sensitivity except for PHS whose capacity is always fixed by the maximum allowed value. Battery capacity ranges from 7.6 to more than $279 G W h_{e}$, nearly four times the capacity in the reference cost scenario (Figure 6d1), and methanation ranges from 7 to $33.5 \mathrm{TWh}$, more than twice the capacity in the reference cost scenario (Figure 6d2).

This analysis also highlights some patterns of substitutability and complementarity between technologies. Obviously, each option is particularly influenced by its own cost, but also by the cost of other technologies. In particular, a higher cost of methanation entails much more offshore wind and vice-versa. Indeed, electricity from offshore wind suffers from a higher cost per MWh produced than other VREs but its production is more stable, generating less need for storage. Conversely a higher cost of batteries reduces solar capacity: batteries are especially interesting when energy must be stored for a few hours, so they complement solar technology.

Finally, the system-wide $\operatorname{LCOE}^{1}$ and the average power price are much more influenced by the cost of generation technologies than by that of storage technologies ${ }^{2}$. Keeping the reference investment cost scenario for power production technologies, changing the investment cost of battery and

\footnotetext{
${ }^{1}$ The system-wide LCOE is calculated as the cost of the electricity system (including production and storage) divided by the electricity consumption.

${ }^{2}$ Schlachtberger et al. (2018) find nearly no effect of storage cost variation on the final cost of the electricity system, which is in accordance with our conclusions.
} 
methanation storage options from the lowest storage investment cost scenario (both -50\%) to the highest storage investment cost scenario (both $+50 \%$ ) changes the overall system-wide LCOE from $€ 46 / \mathrm{MWh}$ to $€ 51 / \mathrm{MWh}$, while changing the investment cost of three VRE power production technologies from the lowest cost scenario to the highest cost one (keeping the storage options at the reference cost scenario), changes the overall system-wide LCOE from $€ 37 / \mathrm{MWh}$ to $58 € / \mathrm{MWh}$.
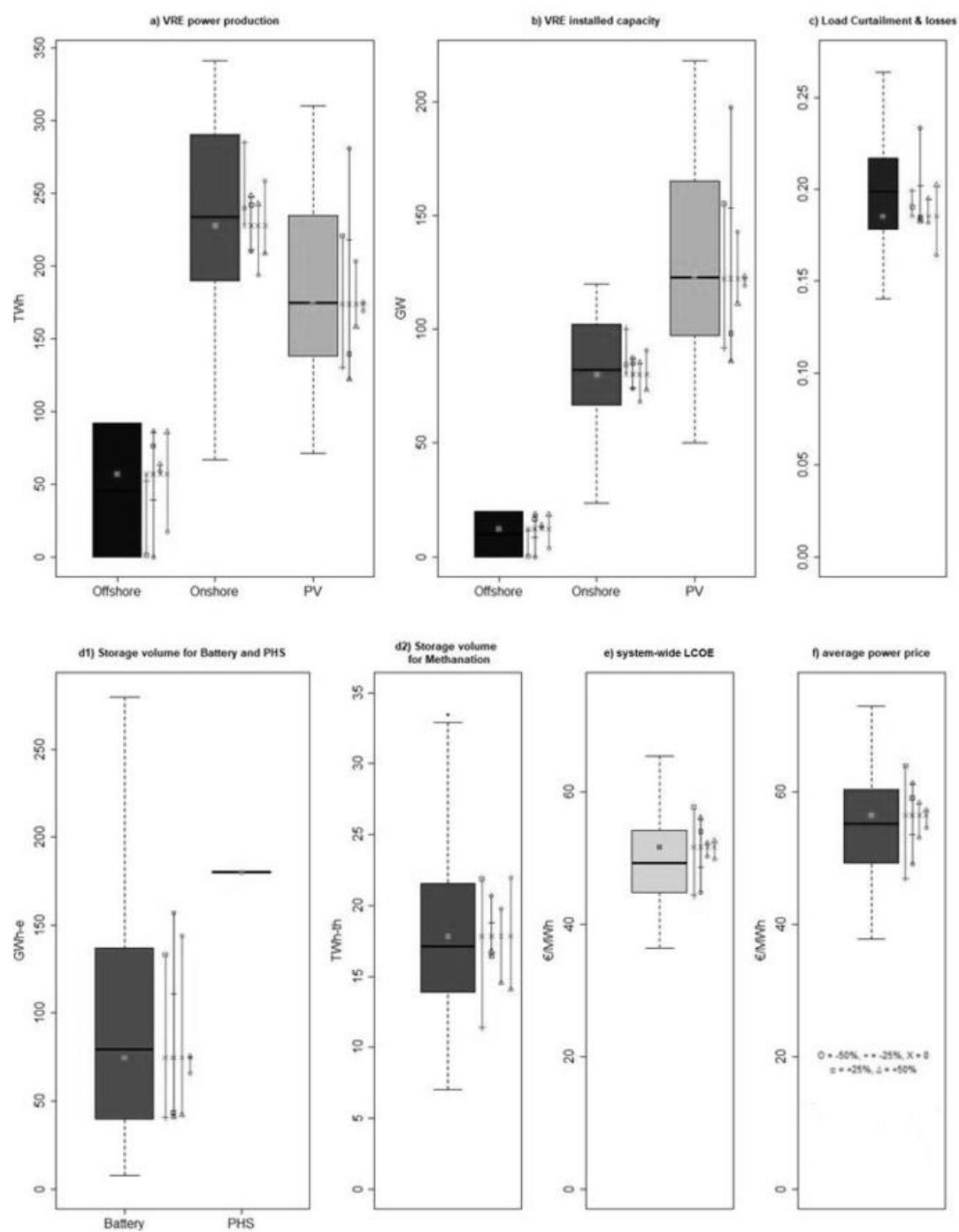

Figure 6 Optimization results for the representative year (2006) over the 315 future cost projection scenarios. (a) power production and (b) installed capacity of each VRE resource; (c) load curtailment and storage losses; (d) needed storage volume in $G W h_{e}$ for batteries and pumped hydro storage (d1) and in TWh for methanation (d2); (e) systemwide $L C O E$ in $€ / M W h_{e}$; (f) average power price in $€ / M W h_{e}$. The square-shaped points show the reference cost scenario. The lines beside whisker plots show the impact of varying separately the cost of one technology, keeping all other technologies at their reference cost, from left to right: variation of offshore and onshore wind power (by 25\%), solar PV (by 50\%), battery storage (by 50\%) and methanation (by 50\%). 


\subsection{However, optimizing the capacity mix based on wrong cost assumptions hardly increases costs}

Globally, the previous cost sensitivity analysis confirms that the optimal power mix is highly sensitive to technology costs. Thus, a decision maker might be tempted to favor a flexible policy over a more rigid one, at the expense of visibility for investors. However, a high cost sensitivity of the optimal power mix does not imply a high cost for choosing a non-optimal mix. In the case of highly substitutable technologies, a small change in cost will lead to a strong shift in the optimal mix but choosing one mix or the other would not change total cost much.

The question we aim to answer in this subsection is the following: "If we decide now a trajectory of renewable capacities for the future based on current cost estimates, could it entail a high over-cost if our assumptions of technology costs are wrong"? To answer that question, we use the installed capacities of generation and storage technologies optimized for the reference cost scenario, and we calculate the system-wide LCOE for this "rigid capacity" across our 315 cost scenarios (Figure 7). The system-wide LCOE is necessarily equal to or higher than that of the "flexible capacity", the difference being the "regret" from basing the optimization on the wrong cost assumptions.

In most cases the regret is remarkably low given the wide range of cost scenarios considered: for the cost scenarios considered, the average value is $4 \%$ i.e. $€ 2 / M W h_{e}$, the third quartile is $6 \%$, and the regret is below $9 \%$ in $95 \%$ of the scenarios. A close examination of the 14 cost scenarios with the largest regret (more than 2 billion $€ /$ year, i.e. around $10 \%$ ) shows that all but one concern scenarios in which the cost of onshore or offshore wind, or both, is lower than expected. Hence the regret in this scenario stems from having installed too little windpower. The only exception is a scenario in which PV and batteries are 50\% cheaper than in the reference scenario, onshore at the reference cost, offshore $25 \%$ cheaper and methanation $50 \%$ more expensive. In this case only, the regret stems from having not installed enough PV and batteries.

The average system-wide LCOE for the rigid capacity mix (black vertical line in Figure 7) equals the system-wide LCOE under the reference cost scenario (dark grey vertical dashed line). This result is due to the symmetric distribution of technology cost shocks and the linear nature of the model, and can be understood as follows: starting from the system optimized over the reference cost scenario, a $+25 \%$ technology cost shock entails a change in system-wide LCOE by the same amount (in absolute value) as a $-25 \%$ technology cost shock, so the average system-wide LCOE for the rigid capacity mix is the same as the system-wide LCOE without uncertainty, i.e. the system-wide LCOE in the reference cost scenario (dark grey dashed vertical line in Figure 7). 
The average system-wide LCOE for the flexible capacity mix (dark grey vertical line in Figure 7) is obviously lower than the rigid one, since optimization is based on accurate information - thus it is also lower than the system-wide LCOE in the reference cost scenario. In this sense, uncertainty actually reduces the expected system-wide LCOE - because we allow optimizing the mix depending on uncertainty realizations.

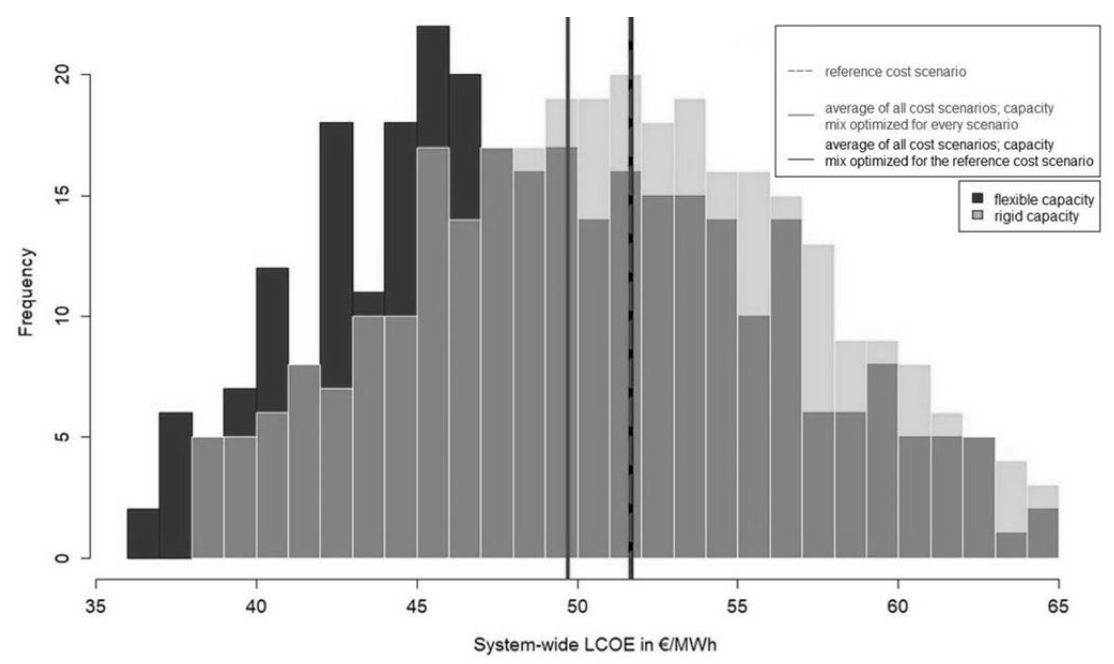

Figure 7 Distribution of system-wide LCOE across cost scenarios. The dark grey distribution represents optimal energy mixes; the light grey distribution is computed using the capacities of the reference scenario.

\section{Discussion \& Conclusion}

\subsection{Comparison with current cost and existing studies}

Some authors have argued that the storage facilities required for a fully renewable power system would massively increase the power system cost (e.g. Sinn, 2017, whose conclusions have been challenged by Zerrahn et al., 2018). In our reference cost scenario, storage (batteries, PHS and methanation) accounts for only $14.5 \%$ of the system cost, vs. $85.5 \%$ for electricity generation (Appendix 6). Moreover, we have seen that the system-wide LCOE is much more robust to the cost of the storage technologies than to that of PV and wind. Hence the importance of the storage cost should not be overemphasized.

According to the latest quarterly report from the French energy regulator (CRE, 2019), 35\% of a typical electricity bill (varying between 170€/MWh and $200 € / M W h$ depending on the tariff chosen and consumption profile) represents electricity production, which thus costs between $59 € / \mathrm{MWh}$ and $70 € / \mathrm{MWh}$. Thus, the cost of a 100\% renewable electricity system for France in 2050 would be lower than or similar to that of the current power system.

20 
These results contrast with those of Krakowski et al. (2016) who find an annualized cost of more than $€ 60 \mathrm{bn} / \mathrm{yr}$. in their scenario 100RES2050 (cf. their Fig. 23) vs. $€ 21$ bn/yr. in ours. The explanation does not stem from their investment cost assumptions, which are similar to ours (cf. their Table 1). One explanation might be that they take a higher discount rate, but they do not disclose it so we cannot verify this hypothesis. Partial explanations are (i) lower VRE capacity potentials (70GW for wind and $65 \mathrm{GW}$ for solar power vs. $140 \mathrm{GW}$ for wind and $218 \mathrm{GW}$ for solar power in current study) which result in very high power import costs, (ii) very low storage availability, which is only short-term storage with very low efficiency and (iii) the assumption of perfect correlation between offshore and onshore wind power technologies, which leads to a lower complementarity between these technologies. Moreover, they base their wind production profiles on observed power generation in 2012, which neglects the fact that advanced turbines generate electricity more constantly than those installed in the past (Hirth and Müller, 2016).

Villavicencio (2017) finds even higher annualized cost: more than $€ 180 \mathrm{bn} / \mathrm{yr}$. for $100 \%$ renewables, i.e. more than 8 times our result. Several factors may explain this huge difference. First, he takes a real discount rate of $7 \% / y r$. This is much higher than ours, which corresponds to the rate recommended for socioeconomic analysis in France (4.5\%). Second, his investment cost for PV is much higher than ours: $€ 3.6 / W_{e}$, while the current investment cost at utility scale is around $\$ 1 / W_{e}$ (Lazard, 2019). This explains why PV does not appear in his reference scenario (F1) with $100 \%$ renewables. Third, total demand is higher than ours $\left(512 T W h_{e}\right.$ vs. $\left.422 T W h_{e}\right)$.

Moreover, recent market observations make us think that our high-cost scenario for offshore wind is rather unlikely, since many recent calls for tenders have resulted in purchasing power agreements at a very low price, throughout Western Europe. This has led the IEA (2019) to project that by 2040 the global average offshore wind investment cost would fall to $\$ 1900 / \mathrm{kW}$ ( $€ 1700 / \mathrm{kW}$ at the current market rate), slightly less than our low-cost scenario.

However, our results are based on simplifying assumptions. In the remainder of this section, we address several factors which could push our estimates up or down.

\subsection{Model limitations}

\section{Factors which could push costs up}

\section{Cost of the transmission and distribution network}

Our system-wide LCOE includes storage costs, as well as some network costs: the connection costs are included in the JRC cost estimates we use, as well as the French "quote-part", which represents the network upgrade costs over the 
next five to ten years. Dividing France into several nodes in order to account for transmission costs and internal congestion is numerically demanding (increasing the run-time of a single year model from 10 minutes to more than 40 hours for a 4-node model), therefore, we applied a single node model for weather-year selection, sensitivity analysis and robustness study. But to assess the importance of the internal congestion issue, we developed a 4-node version of EOLES_elecRES model, which leads to an increase by less than $7 \%$ in the system cost, slightly increasing the load curtailment with no significant change in the energy mix once both wind power generation technologies are aggregated. The results of a 4-node version of this study for year 2006 and the central cost scenario can be found in appendix 10 .

Admittedly, a $100 \%$ power mix would require some additional upgrade costs, in particular in the distribution network, so it would be preferable to have a model that endogenously represents network costs. However, distribution costs are difficult to model, as they vary with each specific situation: is the installation far from an existing line? Is the power of the line enough or should it be increased?

Moreover, several recent studies indicate that the network cost differential across scenarios featuring more or less renewable energies would be limited:

- According to RTE (2018a), for a $71 \%$ renewable electricity mix (the socalled Watt scenario for 2035) in France, the extra network costs would be in the order of $€ 1 \mathrm{bn}$./yr., less than $5 \%$ of the total production and storage cost. However, the relationship is not linear and it cannot be easily extrapolated for higher proportions of renewables.

- Two studies by ADEME $(2015,2018)$ conclude that the cost of renovating the French network in any event, which is planned to take place before 2030, will be at least one order of magnitude more than the cost required to strengthen the grid for a fully renewable power network.

- EirGrid $^{1}$ (the Irish electricity network operator), estimates that for an electricity mix with nearly $90 \%$ of renewables, the reinforcement required to integrate VREs will cost no more than $€ 1 / M W h_{e}$.

These studies justify why the distribution network cost is not modelled in longterm planning models, including ours.

\section{Discount rate}

Some studies use higher discount rates than ours, e.g. $7 \%$ in Villavicencio (2017), as mentioned above. This would increase the annualized cost, especially for capital-intensive technologies. While higher rates may well be used by private companies, $4.5 \%$ is already much higher than both the risk-free real

${ }^{1}$ http://www.eirgridgroup.com/newsroom/record-renewable-energy-o/index.xml 
interest rate available on financial markets and expected GDP growth over the next few decades. Using a higher rate in a socioeconomic analysis means than future generations would be penalized when compared to current ones, which can hardly be defended on ethical grounds.

Table A.10 in Appendix 9 provides a sensitivity analysis in which the discount rate varies from $2 \%$ to $7 \%$. Increasing the discount rate from $4.5 \%$ to $7 \%$ raises the total annual cost from $€ 21.86$ billion to $€ 25.72$ billion. The most affected technology is offshore wind, the decrease in which is offset by an increase in onshore wind. This higher impact of the discount rate on offshore wind can be explained by its longest lifespan, which makes it more sensitive to the discount rate than onshore wind or solar PV. To give an idea of the magnitude, increasing the discount rate from $4.5 \%$ to $7 \%$ would increase the total annual cost from $€ 21.86$ billion to $€ 25.72$ billion.

\section{Perfect weather forecasts}

Our optimization has been conducted on the assumption that the weather is known for the whole period. With imperfect weather forecasts, the cost would be higher, but such an optimization for a country-scale system would be computationally challenging. Gowrisankaran et al. (2016) have performed such an optimization just for solar energy, on a limited geographical scale, and have found that "intermittency overall is quantitatively much more important than unforecastable intermittency." However, whether this conclusion would hold for a complex, multi-energy system is an open question.

\section{Climate change}

Climate change will impact both electricity demand and supply. The effect on demand is taken into account through an increase in demand for air conditioning and a decrease in demand for space heating (section 2.1 above).

Concerning supply, the production of wind farms and PV panels will be affected by climate change but based on our synthesis of the scientific literature these effects should be limited in France. Tobin et al. (2015) conclude, based on an ensemble of 15 regional climate projections, that for the period 2031-2060, the impact of climate change on the production of the French windfarms will be somewhere between $-3 \%$ and $+3 \%$, (their Figure 3.b). The same conclusion stands for PV whose production will not be impacted by climate change by more than plus or minus $2 \%$ according to Jerez et al. (2015, Figure 3). 


\section{Factors which could bring costs down}

\section{Demand-side management}

Our model does not feature price-elastic electricity demand or flexibility in the power consumption profile, because this would have required debatable assumptions. Moreover, the demand profile, taken from ADEME (2015), is already flatter than the current one. Including these features would reduce the need for storage and the related energy losses. We studied demand side management (DSM) in a previous version of the EOLES model. As a result, part of the battery capacity was replaced by DSM and system cost was slightly lower. We decided not to include DSM because its cost is difficult to estimate.

\section{Interconnection with neighboring countries}

Many studies have shown that interconnections with neighboring countries can significantly reduce the cost of a fully renewable system. For instance, AnnanPhan and Roques (2018) have shown that power price volatility can be reduced by cross-border exchanges with neighboring countries. Indeed, this allows benefitting from the differences in climatic and weather conditions between the countries concerned.

\section{Spatial optimization of renewable energy capacities}

As mentioned above, we do not optimize the quantity of renewables at every location but only the aggregate capacity, which is thus scaled-up compared to the value observed in 2017. A lower system cost would be obtained by optimizing their location, which would presumably lead to greater capacity in windier or sunnier locations, although this effect would be mitigated by the need to obtain a flatter aggregate generation profile. Yet this would make the model computationally intractable and might lead to unrealistic concentrations of onshore wind in some locations.

\section{Neither vehicle-to-grid nor second-hand batteries}

We have not considered vehicle-to-grid i.e. the possibility that electric vehicle batteries could be used to provide flexibility in the electricity system. Yet the storage capacity of electric vehicles may be huge by 2050: The French TSO RTE (2018a) estimates it at $900 T W h_{e}$, about ten times the battery capacities in our reference cost scenario. Mobilizing even a small part of this capacity for power storage would bring down the system-wide LCOE, but we have preferred not to include this option because the impact on battery lifetime is still being debated. Another possibility is to recycle used car batteries as stationary batteries, but again, we believe that modeling this option would require precise assumptions on battery degradation. 


\subsection{Conclusion}

In this article, we have studied the sensitivity of optimal fully renewable power systems to technology cost. To that end, we have developed EOLES_elecRES, a model optimizing investment and dispatch in the power sector with a particular focus on the modelling of storage technologies and applied it to study fully renewable power systems in France. We have built 315 cost scenarios by combining assumptions about the long-term cost of the key power generation and storage technologies.

Our results indicate that even though the technologies involved in a fully renewable power system are very different, they will become by and large substitutable in the coming years. For instance, if batteries are $50 \%$ more expensive than expected, the optimal energy mix includes fewer batteries and less $\mathrm{PV}$, but this is compensated for by additional wind power, with a very limited impact on the system-wide LCOE. On the contrary, if wind power is 25\% more expensive than expected, the optimal mix obviously includes less of this technology, but this is compensated for by more PV and storage.

Overall, the impact of storage cost should not be overestimated: even in a $100 \%$ renewable power system, storage (batteries, PHS and methanation) accounts for only $14.5 \%$ of the system cost, vs. $85.5 \%$ for electricity generation. Were our model to include demand-side management, interconnections with neighboring countries, vehicle-to-grid or second-hand batteries, the share of storage in overall cost would be even lower.

Across all cost scenarios, the system-wide LCOE, including generation and storage, ranges from $€ 36.5$ to $€ 65.5 / M W h_{e}$, depending on the cost scenario, with an average value of $€ 50 / M W h_{e}$. This is cheaper than today's value ( $€ 59$ 70). Moreover, setting a capacity target in advance for every technology would only increase the system-wide LCOE by $€ 2 / \mathrm{MWh}_{\mathrm{e}}$ averaged over the 315 cost scenarios compared to the optimum mix, even if costs vary by $+/-25 \%$ for wind and $+/-50 \%$ for solar and storage.

Finally, our analysis shows that the optimal power mix is highly sensitive to the chosen weather-year and to the cost assumptions. In the literature, many analyses of the power mix are still based on a unique weather-year, chosen for data availability rather than representativeness. Our result thus calls for caution over such conclusions on the optimal power mix, when they are based on a limited number of weather-years or cost scenarios.

Our results have the following policy implications. First, they indicate that a fully renewable power system in France can hardly be dismissed on economic grounds. Second, given the massive scale-up required for wind and PV capacities (cf. Appendix 8), investment should be boosted in both technologies.

25 
Last, while the optimal mix is highly dependent on technologies costs assumptions, these investments should not be delayed because even if the energy mix is optimized based on cost assumptions which turn out to be wrong, the extra cost is low. This result calls for providing visibility to investors, even if it entails reducing flexibility in the policy design. It echoes the necessary "preservation of incentives for continued investment" highlighted by Yatchew (2016) in the context of renewable energies.

This work could be extended in many directions, for example including the other power generation technologies that entail low direct $\mathrm{CO}_{2}$ emissions: $\mathrm{CO}_{2}$ capture and storage and nuclear power. Their cost and the possibility of storing massive quantities of $\mathrm{CO}_{2}$ being very uncertain in the French context, we decided not to include them in the present study, but they could be considered in future work. Additional coupling with the gas sector or with electric vehicles could also be considered. These would provide further flexibility options to the power system and would thus probably reinforce the conclusions of this study. 


\section{References}

Abrell, J., Rausch, S., \& Streitberger, C. (2019). Buffering volatility: Storage investments and technology-specific renewable energy support. CER-ETHCenter of Economic Research at ETH Zurich, Working Paper, 19, 310

ADEME (2013). L'exercice de prospective de l'ADEME "Vision 2030-2050" document technique.

ADEME (2015). Vers un mix électrique $100 \%$ renouvelable. https://www.ademe.fr/sites/default/files/assets/documents/mix-electriquerapport-2015.pdf.

ADEME (2018). Trajectoires d'évolution du mix électrique à horizon 2020 2060. ISBN: 979-10-297-1173-2

Annan-Phan, S., \& Roques, F. A. (2018). « Market Integration and Wind Generation: An Empirical Analysis of the Impact of Wind Generation on CrossBorder Power Prices.” The Energy Journal 39(3), 1-25.

Arditi, M., Durdilly, R., Lavergne, R., Trigano, É., Colombier, M., Criqui, P. (2013). Rapport du groupe de travail 2: Quelle trajectoire pour atteindre le mix énergétique en 2025 ? Quels types de scénarios possibles à horizons 2030 et 2050, dans le respect des engagements climatiques de la France ? Tech. rep., Rapport du groupe de travail du conseil national sur la Transition Energétique.

BNEF (2017). Lithium-ion battery costs and markets. https://data.bloomberglp.com/bnef/sites/14/2017/07/BNEF-Lithium-ion-batterycosts-and-market.pdf

Brown, T. W., Bischof-Niemz, T., Blok, K., Breyer, C., Lund, H., \& Mathiesen, B. V. (2018). Response to 'Burden of proof: A comprehensive review of the feasibility of $100 \%$ renewable-electricity systems'. Renewable and sustainable energy reviews, 92, 834-847.

Cerema, 2017. Photovoltaïque au sol. https://www.collins.fr/fr/actualites/photovoltaique-au-sol

Collins, S., Deane, P., Gallachóir, B. Ó., Pfenninger, S., \& Staffell, I. (2018). "Impacts of inter-annual wind and solar variations on the European power system.” Joule 2(10), 2076-2090.

CRE (2018). Observatoire des marchés de détail de l'électricité et du gaz naturel du 3 e trimestre 2018.

https://www.cre.fr/content/download/20125/256999. 
CRE (2019). Observatoire des marchés de détail de l'électricité et du gaz naturel du 2e trimestre 2019. https://www.cre.fr/content/download/21350/272226

ENEA Consulting (2016). The potential of Power-to-Gas. https://www.enea-consulting.com/sdm downloads/the-potential-of-power-togas/

Enevoldsen, P., Permien, F. H., Bakhtaoui, I., von Krauland, A. K., Jacobson, M. Z., Xydis, G., ... \& Oxley, G. (2019). How much wind power potential does Europe have? Examining European wind power potential with an enhanced socio-technical atlas. Energy Policy, 132, 1092-1100

ENTSO-E (2013). Network Code on Load-Frequency Control and Reserves 6, $1-68$.

Ericsson, K. (2017). "Biogenic carbon dioxide as feedstock for production of chemicals and fuels: A techno-economic assessment with a European perspective.” Environmental and Energy System Studies, Lund University: Miljö- och energisystem, LTH, Lunds universitet.

FCH JU (2015). Commercialisation of energy storage in Europe: Final report.

FEE (2019), Eolien en mer, enjeux et perspectives. https://fee.asso.fr/eolien-enmer/enjeux-et-perspectives/

Gowrisankaran, G., Reynolds, S. S., \& Samano, M. (2016). Intermittency and the value of renewable energy. Journal of Political Economy, 124(4), 11871234.

Hirth, L. (2015): "The Optimal Share of Variable Renewables". The Energy Journal 36(1), 127- 162. doi:10.5547/01956574.36.1.6.

Hirth, L., \& Müller, S. (2016). System-friendly wind power: How advanced wind turbine design can increase the economic value of electricity generated through wind power. Energy Economics, 56, 51-63.

Hirth, L., Ueckerdt, F., \& Edenhofer, O. (2016). Why wind is not coal: on the economics of electricity generation. The Energy Journal, 37(3).

Huld T, Gottschalg R, Beyer HG, Topič M. (2010). "Mapping the performance of PV modules, effects of module type and data averaging." Solar Energy 2010;84(2):324-38.

IEA (2019). Offshore Wind Outlook 2019 - World Energy Outlook Special Report. IEA, Paris. 
Jerez, S., Tobin, I., Vautard, R., Montávez, J. P., López-Romero, J. M., Thais, F., ... \& Nikulin, G. (2015). The impact of climate change on photovoltaic power generation in Europe. Nature communications, 6, 10014.

Joskow, P. L. (2011). Comparing the costs of intermittent and dispatchable electricity generating technologies. American Economic Review, 101(3), 23841.

JRC (2014) Energy Technology Reference Indicator Projections for 2010-2050. EC Joint Research Centre Institute for Energy and Transport, Petten.

JRC (2017) Cost development of low carbon energy technologies - Scenariobased cost trajectories to 2050, EUR 29034 EN, Publications Office of the European Union, Luxembourg, 2018, ISBN 978-92-79-77479-9, doi:10.2760/490059, JRC109894.

Jülch, V., Telsnig, T., Schulz, M., Hartmann, N., Thomsen, J., Eltrop, L., \& Schlegl, T. (2015). A holistic comparative analysis of different storage systems using levelized cost of storage and life cycle indicators. Energy Procedia, 73, 18-28.

Krakowski, V., Assoumou, E., Mazauric, V., \& Maïzi, N. (2016). "Feasible path toward 40-100\% renewable energy shares for power supply in France by 2050: A prospective analysis." Applied energy 184, 1529-1550.

Lauret P, Boland J, Ridley B. (2013). "Bayesian statistical analysis applied to solar radiation modelling." Renewable Energy 2013;49:124-7.

Lazard, N. (2019). Lazard's Levelized Cost of Energy Analysis-Version 13.0.

Moraes, L., Bussar, C., Stoecker, P., Jacqué, K., Chang, M., \& Sauer, D. U. (2018). "Comparison of long-term wind and photovoltaic power capacity factor datasets with open-license." Applied Energy 225, 209-220.

NégaWatt (2017). Scénario négaWatt 2017-2050 :

https://negawatt.org/IMG/pdf/synthese_scenario-negawatt_2017-2050.pdf

Palmintier, B. (2014). Flexibility in generation planning: Identifying key operating constraints. In 2014 power systems computation conference (pp. 1-7). IEEE, August.

Perrier, Q. (2018). “The second French nuclear bet.” Energy Economics, 74, 858-877.

Pfenninger, S., Staffell, I. (2016). "Long-term patterns of European PV output using 30 years of validated hourly reanalysis and satellite data." Energy 114, pp. 1251-1265. doi: 10.1016/j.energy.2016.08.060 
Pierrot M. (2018). The wind power. http://www.thewindpower.net

Quinet, E. (2014). L'évaluation socioéconomique des investissements publics (No. Halshs 01059484). HAL.

Rienecker M.M., Suarez M.J., Gelaro R., Todling R., Bacmeister J., Liu E., et al. (2011). "MERRA: NASA's modern-era retrospective analysis for research and applications.” J Climate 2011;24(14):3624-48

Riesz, J., Gilmore, J., \& MacGill, I. (2016). Assessing the viability of energyonly markets with 100\% renewables: An Australian National Electricity Market case study. Economics of Energy \& Environmental Policy, 5(1), 105-131.

Rogelj J, Shindell D, Jiang K, Fifita S, Forster P, Ginzburg V, Handa C, Kheshgi H, et al. (2018). Chapter 2: Mitigation pathways compatible with $1.5 \mathrm{C}$ in the context of sustainable development. In: Global Warming of $1.5 \mathrm{C}$ - an IPCC special report on the impacts of global warming of $1.5 \mathrm{C}$ above preindustrial levels and related global greenhouse gas emission pathways, in the context of strengthening the global response to the threat of climate change. Intergovernmental Panel on Climate Change.

RTE (2018a). Point d'étape sur les travaux du bilan prévisionnel et du schéma décennal de développement réseau. https://www.concerte.fr/system/files/concertation/2018\%2009\%2028\%20CPSR complet2.pdf

RTE (2018b), Panorama de l'électricité renouvelable au 30 Juin 2018.

RTE (2019), Panorama de l'électricité renouvelable au 30 juin 2019.

https://www.rte-france.com/fr/article/panorama-de-l-electricite-renouvelable

Schlachtberger, D. P., Brown, T., Schäfer, M., Schramm, S., \& Greiner, M. (2018). Cost optimal scenarios of a future highly renewable European electricity system: Exploring the influence of weather data, cost parameters and policy constraints. Energy, 163, 100-114.

Schmidt, O., Melchior, S., Hawkes, A., Staffell, I. (2019). "Projecting the Future Levelized Cost of Electricity Storage Technologies.” Joule ISSN 2542-4351 https://doi.org/10.1016/j.joule.2018.12.008

Sinn, H. W. (2017). Buffering volatility: A study on the limits of Germany's energy revolution. European Economic Review, 99, 130-150.

Staffell, I., Pfenninger, S. (2016). "Using Bias-Corrected Reanalysis to Simulate Current and Future Wind Power Output.” Energy 114, pp. 1224-1239. doi: 10.1016/j.energy.2016.08.068 
Tobin, I., Vautard, R., Balog, I., Bréon, F. M., Jerez, S., Ruti, P. M., ... \& Yiou, P. (2015). Assessing climate change impacts on European wind energy from ENSEMBLES high-resolution climate projections. Climatic Change, 128(1-2), 99-112

Van Stiphout, A., De Vos, K., \& Deconinck, G. (2017). "The impact of operating reserves on investment planning of renewable power systems." IEEE Transactions on Power Systems, 32(1), 378-388.

Villavicencio, M. (2017). “A capacity expansion model dealing with balancing requirements, short-term operations and long-run dynamics." CEEM Working Papers (Vol. 25).

WindEurope (2017). Wind energy in Europe, Scenarios for 2030. 22 September. https://windeurope.org/about-wind/reports/wind-energy-in-europe-scenarios-for2030/

Wiser, R., Jenni, K., Seel, J., Baker, E., Hand, M., Lantz, E., \& Smith, A. (2016). "Expert elicitation survey on future wind energy costs." Nature Energy $1(10), 16135$.

Yatchew, A. (2016). High Shares of Renewable Energy Sources and Electricity Market Reform-Preface. The Energy Journal, 37(Bollino-Madlener Special Issue).

ZEP (2011). The Costs of $\mathrm{CO}_{2}$ Transport. Post-demonstration CCS in the EU. Zero Emissions Platform. http://www.zeroemissionsplatform.eu/downloads/813.html

Zerrahn, A., Schill, W. P., \& Kemfert, C. (2018). On the economics of electrical storage for variable renewable energy sources. European Economic Review, 108, 259-279.

Zeyringer, M., Price, J., Fais, B., Li, P. H., \& Sharp, E. (2018). "Designing lowcarbon power systems for Great Britain in 2050 that are robust to the spatiotemporal and inter-annual variability of weather". Nature Energy 3 (5), 395. 


\section{Appendix 1. Additional information on the JRC 2017 study}

In this JRC report, historic installed capacity of each technology for 2015, learning rate related to each technology and the capital investment cost of each technology in 2015 has been taken as input values, and using three different future installed capacity scenarios, three different future cost trajectories are proposed. Equation (A.1) shows the main methodology used in the cost projection using the learning rate method:

$$
\operatorname{Cost}_{t}=\operatorname{Cost}_{0} \cdot\left(\frac{C_{t}}{c_{0}}\right)^{\delta}
$$

This log-linear relation relates the future cost $\left(\operatorname{Cost}_{t}\right)$ of a technology to the existing cost $\left(\operatorname{Cost}_{0}\right)$, existing installed capacity $\left(C_{0}\right)$ and the future projected installed capacity $\left(C_{t}\right)$ of it using the experience parameter $\delta$. The learning rate $L R$ is related to the experience parameter as it is described in equation (A.2);

$$
L R=1-2^{\delta}
$$

The JRC report uses three different scenarios to project the future installed capacity of each technology, and finally to find the $\frac{C_{t}}{C_{0}}$ ratio for the equation (16). These three scenarios are described in Table A.1;

Table A.1 the chosen scenarios by JRC for the 2050 cost projections of low carbon power production technologies

\begin{tabular}{ll} 
Scenario & \\
\hline Baseline & $\begin{array}{l}\text { This scenario is used to cover the lower end of RES-E } \\
\text { deployment. It is based on the "6DS" scenario of the Energy } \\
\text { Technology Perspectives published by the International Energy }\end{array}$ \\
Agency in 2016. It represents a "business as usual" world in \\
which no additional efforts are taken on stabilizing the \\
atmospheric concentration of greenhouse gases. By 2050, primary \\
energy consumption reaches about 940 EJ, renewable energy \\
supplies about $30 \%$ of global electricity demand and emissions \\
climb to 55 GtCO2.
\end{tabular}


decline to about $4.7 \mathrm{GtCO} 2$ by 2050 .

ProRES The "ProRES" scenario results are the most ambitious in terms of capacity additions of RES-E technologies. In this scenario the world moves towards decarbonization by significantly reducing fossil fuel use, however, in parallel with rapid phase out of nuclear power. CCS does not become commercial and is not an available mitigation option. Deep emission reduction is achieved with high deployment of RES, electrification of transport and heat, and high efficiency gains. It is based on the 2015 "Energy Revolution" scenario of Greenpeace. Primary energy consumption is about $430 \mathrm{EJ}$, renewables supply $93 \%$ of electricity demand and global $\mathrm{CO} 2$ emissions are about $4.5 \mathrm{GtCO} 2$ in 2050.

The used economical parameters for the power production technologies are taken from the 2050 projections of this study for the diversified scenario as an average and more realistic scenario.

\section{Appendix 2. Wind and solar production profiles}

The wind power hourly capacity factor profiles existing in the renewables.ninja website are prepared in four stages:

a) Raw data selection; using NASA's MERRA-2 data reanalysis with a spatial resolution of $60 \mathrm{~km} \times 70 \mathrm{~km}$ provided by Rienecker et al. (2011),

b) Downscaling the wind speeds to the wind farms; by interpolating the specific geographic coordinates of each wind farm using LOESS regression,

c) Calculation of hub height wind speed; by extrapolating the wind speed in available altitudes (2,10 and 50 meters) to the hub height of the wind turbines using logarithm profile law, d) Power conversion; using the primary data from Pierrot (2018), the power curves are built (with respect to the chosen wind turbine), and smoothed to represent a farm of several geographically dispersed turbines using Gaussian filter.

The solar power hourly capacity factor profiles in the renewables.ninja website are prepared in three stages:

a) Raw data calculation and treatment; using NASA's MERRA data with the spatial resolution of $50 \mathrm{~km} \times 50 \mathrm{~km}$. The diffuse irradiance fraction estimated with Bayesian statistical analysis introduced by Lauret et al. (2013) and the global irradiation calculated in inclined plane. The temperature is given at $2 \mathrm{~m}$ altitude by MERRA data set.

b) Downscaling of solar radiation to farm level; values are linearly interpolated from grid cells to the given coordinates.

c) Power conversion model; Power output of a panel is calculated using the relative PV performance model by Huld et al. (2010) which gives temperature dependent panel efficiency curves. 


\section{Appendix 3. Weather-year sensitivity}

The results for each weather-year can be seen in Tables A.2, A.3 and A.4.

Table A.2 installed capacity of each power production technology in $G W_{e}$ and energy storage capacity of each storage technology during each optimization period

\begin{tabular}{|c|c|c|c|c|c|c|c|c|c|}
\hline Year & $\begin{array}{c}\text { Offsho } \\
\text { re }\end{array}$ & $\begin{array}{c}\text { Onsh } \\
\text { ore }\end{array}$ & PV & $\begin{array}{c}\text { rive } \\
\mathbf{r}\end{array}$ & Lake & Biogas & $\begin{array}{c}\text { Batter } \\
\mathbf{y} \\
(\mathbf{G W h})\end{array}$ & $\begin{array}{c}\text { PHS } \\
\text { (GWh) }\end{array}$ & $\begin{array}{c}\text { Methan } \\
\text { ation } \\
\text { (TWh) }\end{array}$ \\
\hline 2000 & 11.46 & 84.14 & $\begin{array}{l}105.7 \\
4\end{array}$ & 7.50 & 13.00 & 18.24 & 60.17 & 180 & 5.52 \\
\hline 2001 & 0.38 & $\begin{array}{l}104.6 \\
2\end{array}$ & $\begin{array}{l}101.1 \\
6\end{array}$ & 7.50 & 13.00 & 28.61 & 41.91 & 180 & 8.45 \\
\hline 2002 & 17.12 & 69.66 & $\begin{array}{l}105.5 \\
5\end{array}$ & 7.50 & 13.00 & 19.16 & 74.70 & 180 & 4.60 \\
\hline 2003 & 10.21 & 90.15 & $\begin{array}{l}106.8 \\
3\end{array}$ & 7.50 & 13.00 & 25.70 & 62.78 & 180 & 5.52 \\
\hline 2004 & 0.00 & $\begin{array}{l}105.2 \\
9\end{array}$ & $\begin{array}{l}113.3 \\
8\end{array}$ & 7.50 & 13.00 & 21.88 & 70.32 & 180 & 15.30 \\
\hline 2005 & 0.00 & $\begin{array}{l}105.8 \\
9\end{array}$ & $\begin{array}{l}110.3 \\
8\end{array}$ & 7.50 & 13.00 & 25.22 & 60.27 & 180 & 9.37 \\
\hline 2006 & 12.36 & 80.08 & $\begin{array}{l}122.1 \\
7\end{array}$ & 7.50 & 13.00 & 32.89 & 74.62 & 180 & 12.90 \\
\hline 2007 & 0.00 & 98.40 & $\begin{array}{l}118.3 \\
3\end{array}$ & 7.50 & 13.00 & 27.61 & 65.73 & 180 & 12.05 \\
\hline 2008 & 0.78 & $\begin{array}{l}101.9 \\
5\end{array}$ & $\begin{array}{l}105.2 \\
0\end{array}$ & 7.50 & 13.00 & 21.76 & 52.03 & 180 & 12.05 \\
\hline 2009 & 11.61 & 89.32 & $\begin{array}{l}107.7 \\
9\end{array}$ & 7.50 & 13.00 & 18.83 & 51.47 & 180 & 6.92 \\
\hline 2010 & 20.00 & 83.64 & $\begin{array}{l}100.5 \\
0\end{array}$ & 7.50 & 13.00 & 22.88 & 40.53 & 180 & 15.81 \\
\hline 2011 & 20.00 & 65.81 & $\begin{array}{l}114.1 \\
7\end{array}$ & 7.50 & 13.00 & 28.32 & 101.33 & 180 & 8.54 \\
\hline 2012 & 0.00 & $\begin{array}{l}103.3 \\
8\end{array}$ & $\begin{array}{l}114.4 \\
9\end{array}$ & 7.50 & 13.00 & 20.36 & 62.43 & 180 & 11.32 \\
\hline 2013 & 10.32 & 92.30 & $\begin{array}{l}100.8 \\
2\end{array}$ & 7.50 & 13.00 & 21.54 & 37.06 & 180 & 10.59 \\
\hline 2014 & 20.00 & 70.23 & $\begin{array}{l}111.4 \\
0\end{array}$ & 7.50 & 13.00 & 18.57 & 80.03 & 180 & 7.69 \\
\hline 2015 & 20.00 & 64.77 & $\begin{array}{l}103.7 \\
8\end{array}$ & 7.50 & 13.00 & 34.09 & 63.19 & 180 & 8.22 \\
\hline 2016 & 20.00 & 69.77 & $\begin{array}{l}114.0 \\
7\end{array}$ & 7.50 & 13.00 & 23.96 & 81.68 & 180 & 8.66 \\
\hline 2017 & 5.29 & $\begin{array}{l}100.7 \\
2\end{array}$ & $\begin{array}{l}111.6 \\
2\end{array}$ & 7.50 & 13.00 & 19.30 & 50.05 & 180 & 11.77 \\
\hline Mean & 9.97 & 87.78 & $\begin{array}{l}109.3 \\
0\end{array}$ & 7.50 & 13.00 & 23.83 & 62.79 & 180 & 7.74 \\
\hline All & 11.77 & 83.30 & $\begin{array}{l}112.2 \\
1\end{array}$ & 7.50 & 13.00 & 33.25 & 66.71 & 180 & 16 \\
\hline
\end{tabular}


Table A.3 Yearly power production of each production technology (in TWh) and capacity factor of VRE resources

\begin{tabular}{|c|c|c|c|c|c|c|c|c|c|c|}
\hline Year & $\begin{array}{c}\text { Offsho } \\
\text { re }\end{array}$ & $\begin{array}{c}\text { Onsh } \\
\text { ore }\end{array}$ & PV & $\begin{array}{c}\text { Rive } \\
\mathbf{r}\end{array}$ & $\begin{array}{c}\text { Lak } \\
\text { e }\end{array}$ & $\begin{array}{c}\text { Biog } \\
\text { as }\end{array}$ & $\begin{array}{c}\text { Offsho } \\
\text { re }\end{array}$ & $\begin{array}{c}\text { Onsho } \\
\text { re }\end{array}$ & PV & OCGT \\
\hline 2000 & 54.1 & 246.4 & $\begin{array}{l}146 . \\
6\end{array}$ & 29.2 & 15.8 & 15 & 0.538 & 0.334 & 0.158 & 0.139 \\
\hline 2001 & 1.8 & 307.3 & $\begin{array}{l}143 . \\
6\end{array}$ & 29.2 & 15.8 & 15 & 0.537 & 0.335 & 0.162 & 0.089 \\
\hline 2002 & 82.1 & 212.4 & $\begin{array}{l}145 . \\
5\end{array}$ & 29.2 & 15.8 & 15 & 0.547 & 0.348 & 0.157 & 0.127 \\
\hline 2003 & 45.0 & 245.3 & $\begin{array}{l}153 . \\
5\end{array}$ & 29.2 & 15.8 & 15 & 0.503 & 0.311 & 0.164 & 0.088 \\
\hline 2004 & 0.00 & 296.5 & $\begin{array}{l}159 . \\
7\end{array}$ & 29.2 & 15.8 & 15 & 0.509 & 0.322 & 0.161 & 0.130 \\
\hline 2005 & 0.00 & 290.2 & $\begin{array}{l}160 . \\
0\end{array}$ & 29.2 & 15.8 & 15 & 0.507 & 0.312 & 0.165 & 0.102 \\
\hline 2006 & 56.9 & 227.8 & $\begin{array}{l}173 . \\
7\end{array}$ & 29.2 & 15.8 & 15 & 0.525 & 0.324 & 0.162 & 0.087 \\
\hline 2007 & 0.00 & 294.7 & $\begin{array}{l}170 . \\
2\end{array}$ & 29.2 & 15.8 & 15 & 0.532 & 0.341 & 0.164 & 0.100 \\
\hline 2008 & 3.7 & 296.2 & $\begin{array}{l}145 . \\
5\end{array}$ & 29.2 & 15.8 & 15 & 0.536 & 0.331 & 0.158 & 0.120 \\
\hline 2009 & 51.4 & 246.9 & $\begin{array}{l}153 . \\
7\end{array}$ & 29.2 & 15.8 & 15 & 0.504 & 0.315 & 0.162 & 0.130 \\
\hline 2010 & 88.5 & 226.7 & $\begin{array}{l}140 . \\
7\end{array}$ & 29.2 & 15.8 & 15 & 0.505 & 0.308 & 0.160 & 0.130 \\
\hline 2011 & 91.5 & 179.8 & $\begin{array}{l}165 . \\
8\end{array}$ & 29.2 & 15.8 & 15 & 0.522 & 0.311 & 0.165 & 0.085 \\
\hline 2012 & 0.0 & 294.0 & $\begin{array}{l}164 . \\
1\end{array}$ & 29.2 & 15.8 & 15 & 0.523 & 0.326 & 0.163 & 0.130 \\
\hline 2013 & 48.2 & 259.7 & $\begin{array}{l}138 . \\
9\end{array}$ & 29.2 & 15.8 & 15 & 0.533 & 0.320 & 0.157 & 0.128 \\
\hline 2014 & 89.2 & 193.9 & $\begin{array}{l}153 . \\
5\end{array}$ & 29.2 & 15.8 & 15 & 0.509 & 0.314 & 0.157 & 0.133 \\
\hline 2015 & 96.3 & 190.9 & $\begin{array}{l}148 . \\
6\end{array}$ & 29.2 & 15.8 & 15 & 0.549 & 0.335 & 0.163 & 0.072 \\
\hline 2016 & 88.1 & 187.0 & $\begin{array}{l}160 . \\
3\end{array}$ & 29.2 & 15.8 & 15 & 0.502 & 0.302 & 0.160 & 0.101 \\
\hline 2017 & 23.4 & 272.5 & $\begin{array}{l}160 . \\
6\end{array}$ & 29.2 & 15.8 & 15 & 0.504 & 0.309 & 0.164 & 0.135 \\
\hline Mean & 45.6 & 248.2 & $\begin{array}{l}154 . \\
7\end{array}$ & 29.2 & 15.8 & 15 & 0.522 & 0.323 & 0.161 & 0.113 \\
\hline All & 53.8 & 235.5 & $\begin{array}{l}158 . \\
8\end{array}$ & 29.2 & 15.8 & 15 & 0.522 & 0.323 & 0.161 & 0.079 \\
\hline
\end{tabular}

Table A.3 shows the total cost, marginal cost and the system-wide $\operatorname{LCOE}^{1}$ for each yearly optimization and for the whole 18 -year optimization.

\footnotetext{
${ }^{1}$ System-wide LCOE (levelized cost of electricity) is an economic assessment of the average total cost to build and operate an electricity system over its lifetime divided by total electricity consumption over that lifetime.
} 
Table A.4 Total cost, average marginal cost (average spot price), levelized cost of electricity, load curtailment and storage related losses of each year

\begin{tabular}{|c|c|c|c|c|c|c|}
\hline year & $\begin{array}{l}\text { Total } \\
\text { Cost } \\
\text { (b€) }\end{array}$ & $\begin{array}{l}\text { System-wide } \\
\text { LCOE } \\
\text { (€/MWh) }\end{array}$ & $\begin{array}{l}\text { Market price } \\
(€ / \mathbf{M W h})\end{array}$ & $\begin{array}{l}\text { Load } \\
\text { Curtailment }\end{array}$ & $\begin{array}{l}\text { Storage } \\
\text { losses }\end{array}$ & $\begin{array}{l}\text { Curtailment } \\
+ \text { loss }\end{array}$ \\
\hline 2000 & 20.23 & 47.89 & 53.83 & 11.64 & 5.06 & 16.70 \\
\hline 2001 & 20.44 & 48.40 & 54.20 & 12.76 & 4.87 & 17.63 \\
\hline 2002 & 19.77 & 46.82 & 54.60 & 10.90 & 4.62 & 15.12 \\
\hline 2003 & 20.83 & 49.31 & 54.21 & 12.38 & 3.76 & 16.14 \\
\hline 2004 & 21.33 & 50.51 & 56.91 & 11.75 & 6.43 & 18.18 \\
\hline 2005 & 21.04 & 49.81 & 54.18 & 11.94 & 5.26 & 17.20 \\
\hline 2006 & 21.82 & 51.65 & 56.46 & 11.99 & 6.53 & 18.52 \\
\hline 2007 & 20.87 & 49.40 & 55.59 & 13.40 & 6.14 & 19.54 \\
\hline 2008 & 20.19 & 47.81 & 55.23 & 11.27 & 5.16 & 16.43 \\
\hline 2009 & 20.71 & 49.02 & 54.72 & 13.02 & 4.47 & 17.49 \\
\hline 2010 & 21.91 & 51.87 & 57.29 & 11.83 & 6.30 & 18.13 \\
\hline 2011 & 21.06 & 49.85 & 54.43 & 10.30 & 4.74 & 15.04 \\
\hline 2012 & 20.87 & 49.41 & 54.81 & 12.67 & 5.80 & 18.47 \\
\hline 2013 & 20.82 & 49.28 & 55.47 & 10.63 & 6.01 & 16.64 \\
\hline 2014 & 20.68 & 48.95 & 56.90 & 10.10 & 4.84 & 14.94 \\
\hline 2015 & 20.29 & 48.04 & 54.18 & 10.12 & 4.66 & 14.78 \\
\hline 2016 & 21.00 & 49.72 & 56.46 & 10.07 & 4.67 & 14.74 \\
\hline 2017 & 21.13 & 50.03 & 55.43 & 12.95 & 5.26 & 18.21 \\
\hline Mean & 20.83 & 49.32 & 55.27 & 11.65 & 5.25 & 16.90 \\
\hline All & 21.33 & 50.50 & 56.01 & 11.52 & 5.34 & 16.86 \\
\hline
\end{tabular}

Table A.5 shows the ranking of each weather-year in correlation with overall 18-year period.

Table A.5 Closest years to the overall 18-year period in term of capacity factor of VRE resources

\begin{tabular}{|l|l|l|l|}
\hline & Closest year & Second closest year & Third closest year \\
\hline Offshore Wind & 2011 & 2012 & 2006 \\
\hline Onshore Wind & 2006 & 2004 & 2012 \\
\hline Solar PV & 2004 & 2006 & 2009 \\
\hline $\begin{array}{l}\text { Overall } \\
\text { - with mean absolute } \\
\text { error } \\
\begin{array}{l}\text { - with mean squared } \\
\text { error }\end{array}\end{array}$ & 2006 (value 0.015) & 2012 (value 0.0236) & 2004 (value 0.028) \\
\hline
\end{tabular}

According to our simulations, 2006 is the best proxy for the whole 18-year period in terms of capacity factor, both using the mean absolute error and the mean squared error. It is the best match for onshore wind, the second best for solar PV and the third best for offshore wind.

The installed capacity of solar power for the year 2006 is $122 \mathrm{GW}$, while it is $112 \mathrm{GW}$ for the whole 18 -year period, an $8 \%$ difference. This value seems high from the graph, but it remains low in comparison with the offshore and onshore 36 
wind power installed capacity variations. Comparatively, for offshore wind power the variation ranges from 0 to $20 \mathrm{GW}$ of installed capacity, while the overall 18-year period optimization results in $11.8 \mathrm{GW}$ of installed capacity. Similarly, the installed capacity of onshore wind power varies from $65 \mathrm{GW}$ to $106 \mathrm{GW}$ while the overall 18-year optimization results in $83 \mathrm{GW}$ of installed capacity. Our main conclusion from these results is the following: the interannual variation of solar power is of minor importance in comparison with the high inter-annual variation of wind power (in particular the relative share of offshore to onshore wind). 


\section{Appendix 4: the EOLES_elecRES model}

\section{Sets and parameters}

Table A.6 presents the sets and indices of the EOLES_elecRES model, Table A.7 the parameters. Throughout the paper, every energy unit (e.g. MWh) or power unit (e.g. MW) is expressed in electricity-equivalent. For instance, some energy is stored in the form of methane, to be transformed later into electricity using open-cycle natural gas plants with $45 \%$ efficiency. In this case, when we indicate that $45 M W h_{e}$ is stored in the natural gas network, it means that 100 MWh of methane is stored, which will allow $45 M W h_{e}$ of electricity to be generated.

Table A.6 Sets and indices of the EOLES_elecRES model

\begin{tabular}{|c|c|c|}
\hline Index & Set & Description \\
\hline$h$ & $\in \mathrm{H}$ & Hour: the number of hours in a year, from 0 to 7659 \\
\hline$m$ & $\in \mathrm{M}$ & $\begin{array}{l}\text { Month: the twelve months, from January to } \\
\text { December }\end{array}$ \\
\hline tec & $\in \mathrm{TEC}$ & $\begin{array}{l}\text { Technologies: The set of all electricity generation } \\
\text { and energy storage technologies (offshore, onshore, } \\
\text { PV, river, lake, biogas, gas, PHS, battery, } \\
\text { methanation) }\end{array}$ \\
\hline gen & $\in \mathrm{GEN} \subseteq \mathrm{TEC}$ & $\begin{array}{l}\text { Generation: Electricity generation technologies } \\
\text { (offshore, onshore, PV, river, lake, biogas, gas) }\end{array}$ \\
\hline vre & $\in \mathrm{VRE} \subseteq \mathrm{TEC}$ & $\begin{array}{l}\text { VRE: Variable renewable electricity generation } \\
\text { technologies (offshore, onshore, PV) }\end{array}$ \\
\hline str & $\in \mathrm{STR} \subseteq \mathrm{TEC}$ & $\begin{array}{l}\text { Storage: Energy storage technologies (PHS, battery, } \\
\text { methanation) }\end{array}$ \\
\hline$n c o m b$ & $\begin{array}{l}\in \quad \mathrm{NCOMB} \subseteq \\
\mathrm{TEC}\end{array}$ & $\begin{array}{l}\text { Non-combustible generation technologies (offshore, } \\
\text { onshore, PV, river, lake, PHS, battery) }\end{array}$ \\
\hline $\operatorname{comb}$ & $\in \mathrm{COMB} \subseteq \mathrm{TEC}$ & $\begin{array}{l}\text { Combustible generation technologies (biogas, } \\
\text { methanation) }\end{array}$ \\
\hline frr & $\in \mathrm{FRR} \subseteq \mathrm{TEC}$ & $\begin{array}{l}\text { Frequency restauration reserves: } \\
\text { contributing to secondary reserves requirements } \\
\text { (lake, PHS, battery, gas) }\end{array}$ \\
\hline
\end{tabular}

Table A.7 Parameters of the EOLES_elecRES model

\begin{tabular}{ccll} 
Parameter & Unit & Value $^{l}$ & Description \\
\hline month $_{h}$ & {$[-]$} & $\begin{array}{l}\text { A parameter to show which month each hour is } \\
\text { in }\end{array}$
\end{tabular}

\footnotetext{
${ }^{1}$ For vectors and matrices, no value is displayed in the Table but the information is available at https://github.com/BehrangShirizadeh/EOLES elecRES.
} 


\begin{tabular}{|c|c|c|c|}
\hline$c f_{\text {vre }, h}$ & {$[-]$} & & $\begin{array}{l}\text { Hourly production profiles of variable } \\
\text { renewable energies }\end{array}$ \\
\hline demand $_{h}$ & {$\left[G W_{e}\right]$} & & Hourly electricity demand profile \\
\hline lake $_{m}$ & {$\left[G W h_{e}\right]$} & & Monthly extractable energy from lakes \\
\hline river $_{h}$ & {$[-]$} & & Hourly run-of-river capacity factor profile \\
\hline$\varepsilon_{\text {vre }}$ & {$[-]$} & & $\begin{array}{l}\text { Frequency restoration requirement because of } \\
\text { forecast errors on the production of each } \\
\text { variable renewable energy }\end{array}$ \\
\hline$q_{t e c}^{e x}$ & {$\left[G W_{e}\right]$} & & Existing capacity by technology \\
\hline annuity $_{\text {tec }}$ & {$\left[\mathrm{M} € / G W_{e} /\right.$ year $]$} & & Annualized capital cost of each technology \\
\hline annuity $_{\text {str }}^{e n}$ & {$[\mathrm{M} € / G W h /$ year $]$} & & $\begin{array}{l}\text { Annualized capital cost of energy volume for } \\
\text { storage technologies }\end{array}$ \\
\hline capex str & {$[\mathrm{M} € / G W /$ year $]$} & & $\begin{array}{l}\text { Annualized capital cost of storage technology } \\
\text { charging power }\end{array}$ \\
\hline$f O \& M_{s t r}^{c h}$ & {$[\mathrm{M} € / G W /$ year $]$} & & $\begin{array}{l}\text { Fixed operation and maintenance cost of storage } \\
\text { technology charging power }\end{array}$ \\
\hline$f O \& M_{\text {tec }}$ & {$\left[\mathrm{M} € / G W_{e} /\right.$ year $]$} & & $\begin{array}{l}\text { Annualized fixed operation and maintenance } \\
\text { cost }\end{array}$ \\
\hline$v O \& M_{t e c}$ & {$\left[\mathrm{M} € / G W h_{e}\right]$} & & $\begin{array}{l}\text { Variable operation and maintenance cost of } \\
\text { each technology }\end{array}$ \\
\hline$\eta_{s t r}^{i n}$ & {$[-]$} & & Charging efficiency of storage technologies \\
\hline$\eta_{s t r}^{\text {out }}$ & {$[-]$} & & Discharging efficiency of storage technologies \\
\hline$q^{\text {pump }}$ & $G W_{e}$ & 9.3 & Pumping capacity for Pumped hydro storage \\
\hline$e_{P H S}^{\max }$ & $G W h_{e}$ & 180 & $\begin{array}{l}\text { Maximum energy volume that can be stored in } \\
\text { PHS reservoirs }\end{array}$ \\
\hline$e_{\text {biogas }}^{\max }$ & $T W h_{e}$ & 15 & $\begin{array}{l}\text { Maximum yearly energy that can be generated } \\
\text { from biogas }\end{array}$ \\
\hline$\delta_{\text {uncertainty }}^{\text {load }}$ & {$[-]$} & 0.01 & $\begin{array}{l}\text { Uncertainty coefficient for hourly electricity } \\
\text { demand }\end{array}$ \\
\hline$\delta_{\text {variation }}^{\text {load }}$ & {$[-]$} & 0.1 & Load variation factor \\
\hline
\end{tabular}

\section{Variables}

The main variables resulting from the optimization are presented in Table A.8. 
Table A.8 Variables of the EOLES_elecRES model

\begin{tabular}{|c|c|c|}
\hline variable & Unit & description \\
\hline$G_{t e c, h}$ & $G W h_{e}$ & Hourly electricity generation by technology \\
\hline$Q_{t e c}$ & $G W_{e}$ & Installed capacity by technology \\
\hline STORAGE $E_{\text {str }, h}$ & $G W h$ & Hourly electricity entering each storage technology (inflow) \\
\hline STORED $D_{\text {str }, h}$ & $G W h_{e}$ & Hourly energy stored in each technology (stock) \\
\hline$S_{s t r}$ & GW & Installed charging capacity by storage technology \\
\hline VOLUME $E_{s t r}$ & GWh & Energy capacity by storage technology \\
\hline$R S V_{f r r, h}$ & $G W_{e}$ & $\begin{array}{l}\text { Hourly upward frequency restoration requirement to manage the } \\
\text { variability of renewable energies and demand uncertainties }\end{array}$ \\
\hline $\operatorname{COST}$ & $b €$ & $\begin{array}{l}\text { Total power system cost, annualized (minus the fixed cost of } \\
\text { already installed capacities). This is the objective function to be } \\
\text { minimized. }\end{array}$ \\
\hline
\end{tabular}




\section{Appendix 5: Transport cost of carbon dioxide for methanation}

The cost of transporting carbon dioxide along a $200 \mathrm{~km}$ onshore pipeline is $€ 4 / t \mathrm{CO}_{2}$, for $100 \mathrm{~km}$ ling pipeline, this transporting cost can be assumed around $€ 2 / t \mathrm{CO}_{2}$. Given that each mole of carbon dioxide weighs 44 grams, and we can produce one mole of methane from one mole of $\mathrm{CO}_{2}$ with an efficiency of $80 \%$ and each mole of methane can produce $802.3 \mathrm{~kJ}$ of thermal energy, considering an OCGT combustion efficiency of $45 \%$ (JRC 2014):

$\frac{1 \mathrm{t} \mathrm{\textrm {CO } _ { 2 }}}{1000000 \mathrm{~g} \mathrm{CO}_{2}} \times \frac{44 \mathrm{~g} \mathrm{CO}_{2}}{1 \mathrm{~mol} \mathrm{CO}_{2}} \times \frac{1 \mathrm{~mol} \mathrm{CO}_{2}}{0.8 \mathrm{~mol} \mathrm{CH}_{4}} \times \frac{1 \mathrm{~mol} \mathrm{CH}_{4}}{802.3 \mathrm{~kJ}} \times \frac{1 \mathrm{~kJ} \mathrm{th}}{0.00022277778 \mathrm{kWh} \mathrm{th}} \times$
$\frac{1 \mathrm{kWh} \mathrm{th}}{0.45 \mathrm{kWh} \text { elec }} \times \frac{1000 \mathrm{kWh} \text { elec }}{1 \mathrm{MWh} \text { elec }}=0.5486 \frac{\mathrm{tCO}_{2}}{\mathrm{MWh} \mathrm{elec}}$

Multiplying this transport cost by $€ 2 / t \mathrm{CO}_{2}$, the $\mathrm{CO}_{2}$ transport cost for methanation becomes €1.0972/MWh. 


\section{Appendix 6: Cost decomposition}

Figure A.1 shows the share of each technology in overall cost of power system (except distribution and transmission costs);

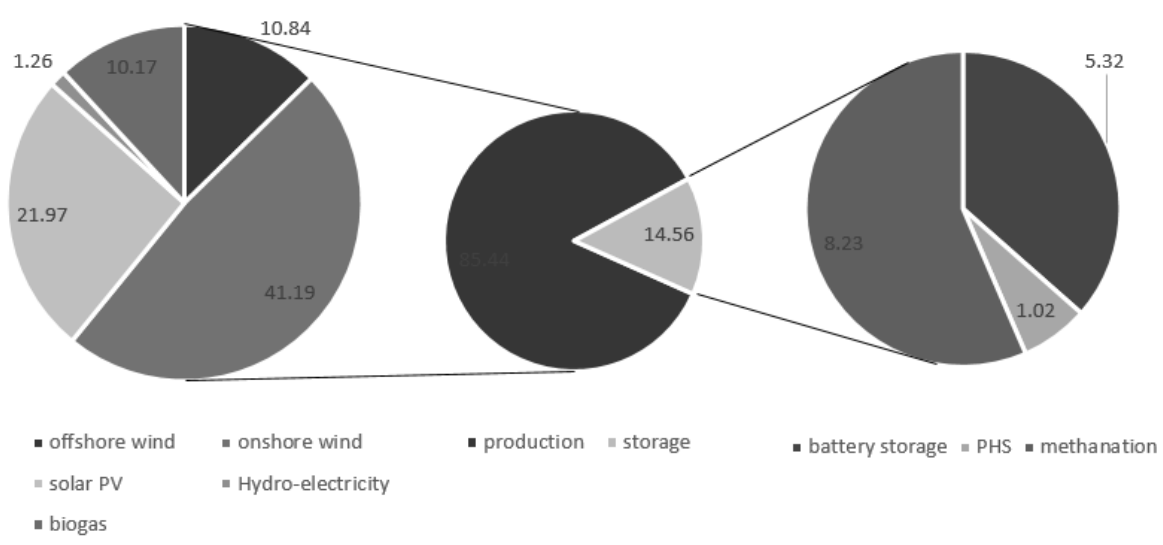

Figure A.1. Overall decomposition of the system cost in percentage for the reference cost scenario 


\section{Appendix 7: Insights on profitability by technology}

In this article, we model an economic optimum, not a decentralized economy. However, in this appendix, we provide some insights on the decentralization of this optimum in the form of a market economy, assuming perfect competition and an energy-only market ${ }^{1}$. In this aim, we consider that the Lagrange multiplier of the adequacy equation (eq. 3) represents the market price. Figure A. 2 below adds to Figure 2 the electricity spot price, defined this way.
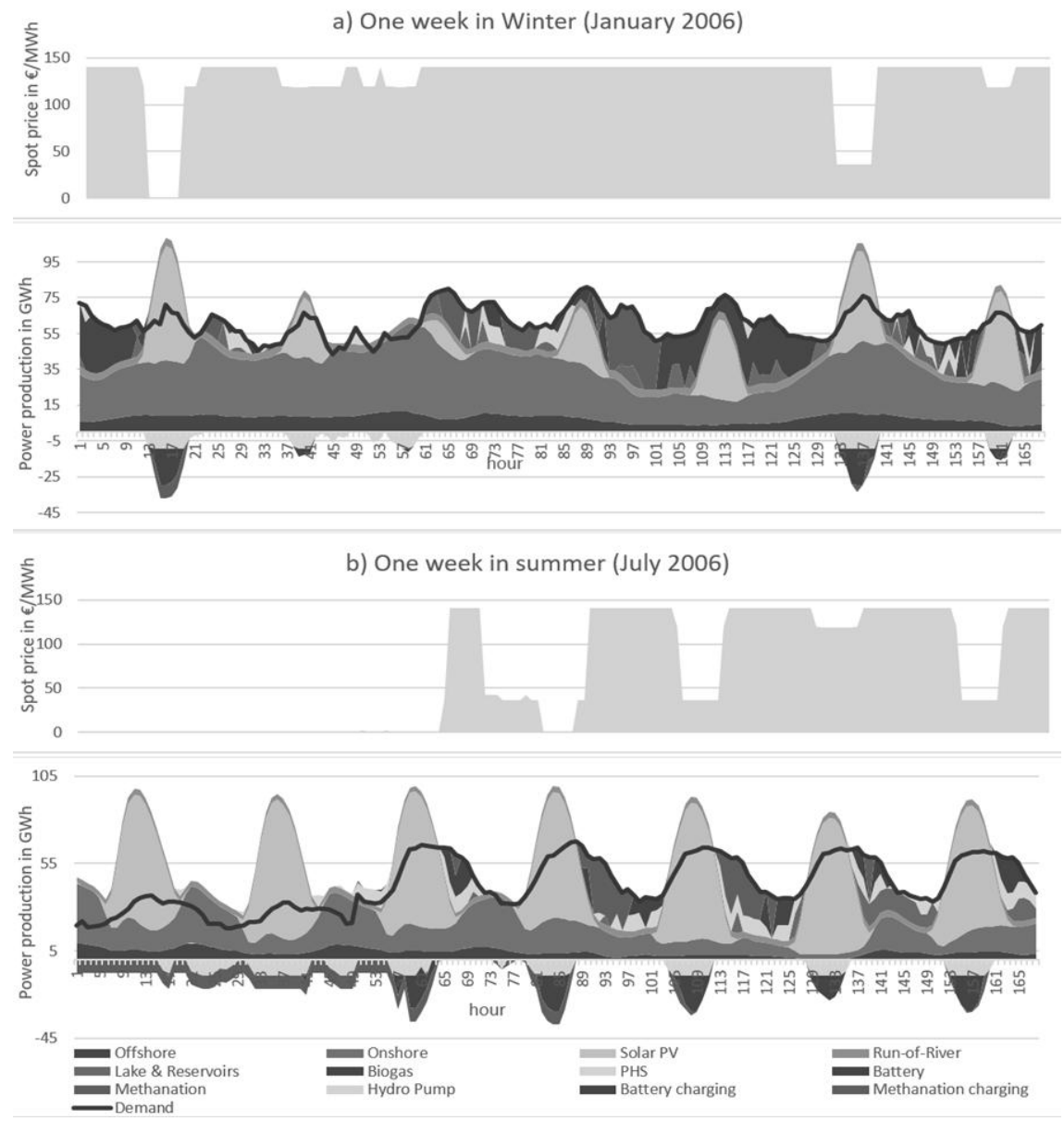

Figure A.2. Hourly power generation, electricity demand, storage charge and discharge profiles and power prices for (a) third week of January (Winter) and (b) third week of July (Summer) 2006

\footnotetext{
1 We do not assess the relevance of supplementing the energy-only market with capacity remuneration mechanisms. On this point, cf. Riesz et al. (2016).
} 
As we can see, the price is often either zero (when there is some excess power generation) or around $€ 140 / \mathrm{MWh}$. Figure A.3. below, which presents the price frequencies, confirms this result: over the year, the price is zero during ca. 3500 hours (out of 8760) and between $€ 140 / \mathrm{MWh}$ and $€ 160 / \mathrm{MWh}$ during ca. 2000 hours. These price ranges are similar to those calculated by Abrell et al. (2019) for Germany, when they assume a storage capacity similar to that resulting from our optimization.

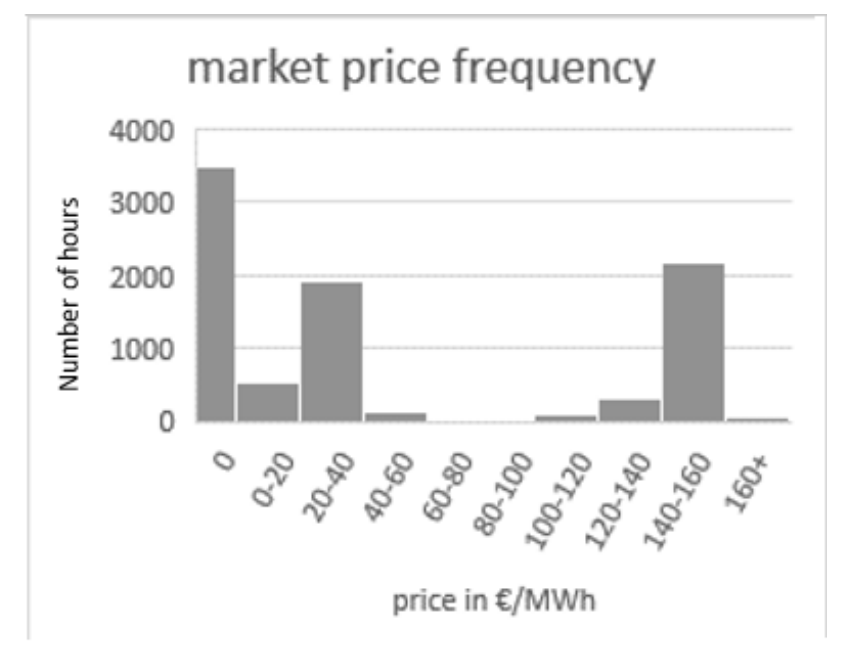

Figure A.3. Market price frequency.

On the basis of these "market prices", we can calculate the average selling price for every technology, and the average buying price for storage technologies. These are presented in Table A.9 together with the LCOE (the levelized cost of electricity produced) the LCOS (levelized cost of storage; cf. Jülch et al., 2015) and the long-term profit, i.e. the difference between the market price and the LCOE.

Table A.9 LCOE/LCOS and average price of electricity sold and bought and unit profit for each technology, for weather-year 2006

\begin{tabular}{|c|c|c|c|c|c|c|c|c|c|c|}
\hline $\begin{array}{l}\text { Prices } \\
(\epsilon / M W h \\
e)\end{array}$ & $\begin{array}{l}\text { offsh } \\
\text { ore }\end{array}$ & $\begin{array}{l}\text { onsh } \\
\text { ore }\end{array}$ & $\begin{array}{l}P \\
V\end{array}$ & lake & $\begin{array}{l}\text { rive } \\
r\end{array}$ & $\begin{array}{l}\text { bioga } \\
s^{*}\end{array}$ & $\begin{array}{l}O C G \\
T^{*}\end{array}$ & $\begin{array}{l}\text { batter } \\
y\end{array}$ & $\begin{array}{l}P H \\
S\end{array}$ & $\begin{array}{l}\text { methanati } \\
\text { on* }\end{array}$ \\
\hline $\begin{array}{l}\text { LCOE/L } \\
C O S\end{array}$ & 41.6 & 39.4 & $\begin{array}{l}27 \\
.6 \\
\end{array}$ & 98.8 & 40.8 & 82.0 & 67.1 & 87.5 & 16.3 & 116.1 \\
\hline $\begin{array}{l}\text { Average } \\
\text { selling } \\
\text { price }\end{array}$ & 41.7 & 39.6 & 28 & $\begin{array}{c}143 . \\
7\end{array}$ & 55.2 & 141.6 & 209.0 & 99.5 & 86.1 & 142.5 \\
\hline $\begin{array}{l}\text { Average } \\
\text { buying } \\
\text { price }\end{array}$ & - & - & - & - & - & - & 141.9 & 21.5 & 23.0 & 26.4 \\
\hline $\begin{array}{l}\text { Long- } \\
\text { term } \\
\text { profit }\end{array}$ & 0.09 & 0.15 & $\begin{array}{l}0 . \\
42\end{array}$ & $\begin{array}{c}38.1 \\
9\end{array}$ & $\begin{array}{c}14.3 \\
9\end{array}$ & 59.57 & 0 & -9.54 & $\begin{array}{c}46.8 \\
3\end{array}$ & 0 \\
\hline
\end{tabular}


* Price of gas sold, converted into electricity-equivalent by dividing the gas price by the energy efficiency of OCGTs.

For most technologies, the long-term profit is close to zero. A large positive profit occurs for biogas and the three hydro technologies. The profitability of hydro is due to the capacity constraint, while for biogas it is due to the production constraint, since these constraints generate a scarcity rent.

Conversely, the reserve requirements generate a negative profit for batteries operators and a (slightly) positive one for PV and wind operators. To fulfil the reserve requirements, the optimization leads to a larger capacity of batteries and lower capacities of PV and wind, compared to a cost-minimization without these requirements. To decentralize the modelled optimum, additional revenue should be paid to battery operators for them to invest on this capacity, e.g. in the form of a capacity market, but we have not modelled such a market to keep the model simple. 


\section{Appendix 8: Renewable capacities compared to potential and other scenarios}

Table A.10 Renewable capacities in our study, capacities currently installed, capacities in other scenarios and available potential

\begin{tabular}{|c|c|c|c|c|c|c|c|c|c|}
\hline & \multirow[b]{2}{*}{$\begin{array}{l}\text { Optim } \\
\text { um in } \\
\text { our } \\
\text { referen } \\
\text { ce cost } \\
\text { scenari } \\
\text { o }\end{array}$} & \multirow[b]{2}{*}{$\begin{array}{l}\text { Curre } \\
\text { nt } \\
\text { capaci } \\
\text { ty, } \\
\text { mid- } \\
2019 \\
\text { (RTE, } \\
\text { 2019) }\end{array}$} & \multicolumn{3}{|c|}{ Other scenarios for 2050} & \multicolumn{4}{|c|}{ Renewable potential } \\
\hline & & & $\begin{array}{l}\text { ADE } \\
\text { ME } \\
(2015)\end{array}$ & $\begin{array}{l}\text { négaW } \\
\text { att } \\
\text { (2017) }\end{array}$ & $\begin{array}{l}\text { ADE } \\
\text { ME } \\
(2018)\end{array}$ & $\begin{array}{l}\text { ADE } \\
\text { ME } \\
(2018)\end{array}$ & $\begin{array}{l}\text { Enevold } \\
\text { sen et al. } \\
\text { (2019) }\end{array}$ & $\begin{array}{l}\text { FEE } \\
(2019 \\
)\end{array}$ & $\begin{array}{l}\text { Cerem } \\
\text { a } \\
(2017)\end{array}$ \\
\hline $\begin{array}{l}\text { Offsh } \\
\text { ore } \\
\text { wind } \\
\end{array}$ & $12 \mathrm{GW}$ & $0 \mathrm{GW}$ & $10 \mathrm{GW}$ & $28 \mathrm{GW}$ & $8 \mathrm{GW}$ & $66 \mathrm{GW}$ & - & $\begin{array}{l}220 \mathrm{G} \\
\mathrm{W}\end{array}$ & - \\
\hline $\begin{array}{l}\text { Onsho } \\
\text { re } \\
\text { wind }\end{array}$ & $80 \mathrm{GW}$ & $16 \mathrm{GW}$ & $\begin{array}{l}96.5 \mathrm{G} \\
\mathrm{W}\end{array}$ & $50 \mathrm{GW}$ & $77 \mathrm{GW}$ & $\begin{array}{l}174 \mathrm{G} \\
\mathrm{W}\end{array}$ & $300 \mathrm{GW}$ & - & - \\
\hline $\begin{array}{l}\text { Solar } \\
\text { PV }\end{array}$ & $\begin{array}{l}110 \mathrm{G} \\
\mathrm{W}\end{array}$ & 9GW & $63 \mathrm{GW}$ & $\begin{array}{l}136 \mathrm{G} \\
\mathrm{W}\end{array}$ & $85 \mathrm{GW}$ & $\begin{array}{l}459 \mathrm{G} \\
\mathrm{W}\end{array}$ & - & - & $\begin{array}{l}776 \mathrm{G} \\
\text { W+ } \\
\text { for } \\
\text { south } \\
\text { of } \\
\text { France }\end{array}$ \\
\hline
\end{tabular}

For our reference cost scenario, the optimal mix features $12 \mathrm{GW}$ of offshore wind (vs. $2 \mathrm{MW}$ as of mid-2019), $80 \mathrm{GW}$ of onshore wind (vs. $16 \mathrm{GW}$, i.e. 5 times more) and $110 \mathrm{GW}$ of solar PV (vs. $9 \mathrm{GW}$, i.e. 13 times more). This yields two related questions: are such surges in installed capacities feasible? How different are they from the other $100 \%$ renewable scenarios for France?

To address the first question, we show in the last four columns of Table A.10 the renewable potential identified by several studies. For each of the three technologies at stake, the capacity resulting from our optimization is much lower than those identified by these studies. Hence there is no physical barrier to the implementation of these capacities.

Yet, many onshore wind projects suffer from local opposition, mostly related to landscape issues. These oppositions may constitute the main obstacle to the implementation of the optimum mix that we have identified for our reference cost scenario. Indeed, reaching $80 \mathrm{GW}$ in 2050 means an increase of $2 \mathrm{GW} / \mathrm{yr}$. on average, from 2018 onwards, a bit less than WindEurope's (2017) "high" 2030 scenario, but almost twice the current rate of increase. Sustaining such a high rate of increase requires a high degree of political determination, given the current opposition faced by many wind projects in France. On the other hand, we have seen that renewable technologies are by and large substitutable, so our intuition is that a scenario with less onshore, more offshore and more PV would not be much costlier. 
To address the second question, we show in Table A.9 (columns 3-6) the capacities installed in the other $100 \%$ renewable scenarios for France, i.e. négaWatt (2017), and Ademe $(2015,2018)$. The négaWatt scenario does not result from an explicit economic optimization while the Ademe scenarios do, but based on different assumptions and models than our study. Our optimal mix is in-between the other scenarios for the three VRE. Moreover, the VRE capacities in these three scenarios are in the range of optimum values presented in Figure 6 based on our 315 cost scenarios, except for offshore wind in the négaWatt scenario because it slightly exceeds our prescribed potential ( $28 \mathrm{GW}$ vs. 20 ). To sum up, our results do not cast doubts on the technological choices made by the authors of these scenarios. 


\section{Appendix 9: Sensitivity to the discount rate}

Table A.11 below shows, for a discount rate ranging from 2 to $7 \%$ per year, the installed capacities and the yearly cost. The latter increases almost linearly with the discount rate. The installed capacity by technology is almost unaffected, the main exception being wind energy. A higher discount rate reduces the share of offshore wind because of its longer lifetime (30 years vs. 25 for onshore wind and $\mathrm{PV}$ ). As a result, when the discount rate rises, offshore wind is partly replaced by onshore wind.

Table A.11 Capacities installed for various discount rates and annual system cost

\begin{tabular}{|l|r|r|r|r|r|r|r|}
\hline \multirow{2}{*}{ Discount rate (\%) } & \multicolumn{7}{|c|}{ Installed capacity (GW) } \\
\cline { 2 - 8 } & $\mathbf{2}$ & $\mathbf{3}$ & $\mathbf{4}$ & $\mathbf{4 . 5}$ & $\mathbf{5}$ & $\mathbf{6}$ & $\mathbf{7}$ \\
\hline Offshore & 20 & 20 & 20 & 12.78 & 0 & 0 & 0 \\
\hline Onshore & 67.93 & 67.59 & 67.8 & 80.16 & 101.4 & 101.17 & 100.95 \\
\hline PV & 122.73 & 122.67 & 121.39 & 121.42 & 122.49 & 122.15 & 122.29 \\
\hline Gas & 33.55 & 33.51 & 33.53 & 33.07 & 32.38 & 32.27 & 32.19 \\
\hline Battery & 20.11 & 20.16 & 20.08 & 20.05 & 19.92 & 20.03 & 20.13 \\
\hline Methanation & 6.91 & 7.12 & 7.33 & 7.36 & 7.86 & 7.93 & 7.97 \\
\hline Lake & 13 & 13 & 13 & 13 & 13 & 13 & 13 \\
\hline River & 7.5 & 7.5 & 7.5 & 7.5 & 7.5 & 7.5 & 7.5 \\
\hline PHS & 9.3 & 9.3 & 9.3 & 9.3 & 9.3 & 9.3 & 9.3 \\
\hline Cost (bn. $\mathbf{\epsilon} / \mathbf{y r}$.) & $\mathbf{1 8 . 2 4 8}$ & $\mathbf{1 9 . 6 2}$ & $\mathbf{2 1 . 0 8}$ & $\mathbf{2 1 . 8 6}$ & $\mathbf{2 2 . 5 8}$ & $\mathbf{2 4 . 4 2}$ & $\mathbf{2 5 . 7 2}$ \\
\hline
\end{tabular}




\section{Appendix 10: Impact of the inter-regional transmission network}

We developed a 4-node version of the EOLES_elecRES model, dividing France into 4 geographical divisions: North-East, North-West, South-East and SouthWest. We added the existing interconnections and the possibility of new investments in overhead transmission lines from each division to the other three divisions, considering an average distance of $400 \mathrm{~km}$ between each division. The new transmission line costs are taken from the JRC 2014 study mentioned in the text (investment cost of $450,000 € / \mathrm{km}$ for a $500 \mathrm{MW}$ overhead transmission line, and $1.5 \%$ of the investment cost as fixed operation and maintenance cost per year). Adding the regional hourly electricity demand (keeping the overall demand for 2050 but using the 2018 repartition of electricity demand for different regions of France from RTE - the French transmission network operator) and hourly VRE profiles from renewable.ninja, keeping the same sources for all the input data, we ran the model for the weather-year 2006.

The preparation of variable renewable energies' capacity factor profiles is as follows: having the hourly profiles for each county (département) in France for each year, we took a weighted average proportional to the existing installed capacity in each county for each region, and we prepared aggregated hourly VRE profiles for each of the four geographic divisions. The technical potential of each renewable energy resource, as well as pumped hydro storage is presented in ADEME's 100\% renewable electricity study (ADEME, 2015) for each of the 12 regions of continental France. By summing them, we defined maximal installable capacity of each renewable technology in each of the four divisions.

The installed capacities and yearly power production of each power generation technology for both the 4-node version and the single-node version of EOLES_elecRES for year 2006 are presented in tables A.12 and A.13 below. The codes can be found on GitHub ${ }^{1}$.

Table A.12 Installed capacity of each electricity production technology (in GW) and volume capacity of each storage technology for the single node and the 4-node versions of EOLES_elecRES

\begin{tabular}{|l|l|l|l|l|l|l|}
\hline Technology & $\begin{array}{l}\text { Region } \\
\text { NE }\end{array}$ & $\begin{array}{l}\text { Region } \\
\text { NW }\end{array}$ & Region SE & $\begin{array}{l}\text { Region } \\
\text { SW }\end{array}$ & $\begin{array}{l}\text { All regions } \\
\text { summed }\end{array}$ & $\begin{array}{l}\text { Single } \\
\text { node } \\
\text { version }\end{array}$ \\
\hline Offshore wind & 0 & 0 & 0 & 0 & 0 & 12.36 \\
\hline Onshore wind & 16.12 & 55 & 4.1 & 30.86 & 106.08 & 80.08 \\
\hline Wind & 16.12 & 55 & 4.1 & 30.86 & 106.08 & 92.44 \\
\hline
\end{tabular}

1 https://github.com/BehrangShirizadeh/EOLES elecRES/blob/master/model/EOLES RE 4regions.g $\underline{\mathrm{ms}}$ 


\begin{tabular}{|l|l|l|l|l|l|l|}
\hline Solar PV & 15.83 & 0 & 77.5 & 35.49 & 128.82 & 122.17 \\
\hline Lake & 0.62 & 0.22 & 8 & 4.6 & 13 & 13 \\
\hline Run-of-river & 1.5 & 0.2 & 4.1 & 1.7 & 7.5 & 7.5 \\
\hline Biogas & 18.16 & 7.73 & 3.95 & 0.91 & 30.75 & 32.89 \\
\hline Battery & 3.56 & 10.43 & 62.59 & 28.71 & 105.29 & 74.62 \\
\hline PHS & 29.34 & 0 & 113.48 & 37.17 & 180 & 180 \\
\hline $\begin{array}{l}\text { Methanation } \\
\text { (TWh) }\end{array}$ & 0 & 4.49 & 7.05 & 2.01 & 13.55 & 12.90 \\
\hline
\end{tabular}

Table A.13 Yearly electricity produced by each technology (in TWh), imports and exports, for the single node and the 4-node versions of EOLES_elecRES

\begin{tabular}{|l|l|l|l|l|l|l|}
\hline $\begin{array}{l}\text { The } \\
\text { technology }\end{array}$ & $\begin{array}{l}\text { Region } \\
\text { NE }\end{array}$ & $\begin{array}{l}\text { Region } \\
\text { NW }\end{array}$ & Region SE & $\begin{array}{l}\text { Region } \\
\text { SW }\end{array}$ & $\begin{array}{l}\text { All regions } \\
\text { summed }\end{array}$ & $\begin{array}{l}\text { Single } \\
\text { node } \\
\text { version }\end{array}$ \\
\hline $\begin{array}{l}\text { Offshore } \\
\text { wind }\end{array}$ & 0 & 0 & 0 & 0 & 0 & 56.90 \\
\hline Onshore wind & 43.87 & 181.67 & 9.86 & 80.92 & 316.32 & 227.80 \\
\hline Wind & 43.87 & 181.67 & 9.86 & 80.92 & 316.32 & 284.70 \\
\hline Solar PV & 19.59 & 0 & 116.37 & 52.26 & 188.22 & 173.72 \\
\hline Lake & 0.74 & 0.27 & 9.40 & 5.41 & 15.82 & 15.82 \\
\hline Run-of-river & 5.84 & 0.97 & 15.96 & 6.62 & 29.19 & 29.19 \\
\hline Biogas & 15 & 0 & 0 & 0 & 15 & 15 \\
\hline Imports & 106.71 & 27.64 & 43.01 & 15.82 & 193.18 & - \\
\hline Exports & 10.74 & 85.44 & 46.62 & 52.25 & 195.05 & - \\
\hline
\end{tabular}

The cost, average system-wide levelized cost of electricity, load curtailment and losses for both versions of EOLES_elecRES model are presented in table A.14.

Table A.14 Main outputs from the single-node and the 4-node EOLES_elecRES models for year 2006

\begin{tabular}{|l|l|l|l|}
\hline The variable & 4-node model & single-node model & Difference in \% \\
\hline Cost (b€/year) & 23.36 & 21.82 & 6.6 \\
\hline $\begin{array}{l}\text { System-wide average } \\
\text { LCOE }\left(€ / \mathrm{MWh}_{\mathrm{e}}\right)\end{array}$ & 55.31 & 51.65 & 6.6 \\
\hline Load curtailment $(\%)$ & 14.13 & 11.99 & 15 \\
\hline Storage loss $(\%)$ & 6.08 & 6.53 & 7.3 \\
\hline Interconnection loss $(\%)$ & 0.9 & - & - \\
\hline
\end{tabular}

Table A.15 provides the interconnection capacity between each of the 4 divisions, and table A.16 the energy flow between each pair of divisions. 
Table A.15 Interconnection capacity among the four divisions considered for France

\begin{tabular}{|l|l|l|}
\hline Pair of divisions & $\begin{array}{l}\text { Interconnection } \\
\text { capacity }(\mathbf{G W})\end{array}$ & $\begin{array}{l}\text { Of which } \\
\text { existing } \\
(\mathbf{G W})\end{array}$ \\
\hline $\mathbf{N E}$ <-> NW & 9.3 & 2 \\
\hline $\mathbf{N E}<->$ SE & 7 & 7 \\
\hline $\mathbf{N E}<->$ SW & 3.73 & 0 \\
\hline $\mathbf{N W}<->$ SE & 7.88 & 0 \\
\hline $\mathbf{N W}<->$ SW & 5 & 5 \\
\hline SE <-> SW & 5 & 5 \\
\hline
\end{tabular}

Table A.16 Annual electricity flow between each pair of divisions

\begin{tabular}{|l|l|l|l|l|}
\hline $\begin{array}{l}\text { Annual power flow } \\
\text { (TWh) }\end{array}$ & to NE & to NW & to SE & to SW \\
\hline From NE & - & 3.13 & 5.89 & 1.72 \\
\hline From NW & 55.55 & - & 23.39 & 9.60 \\
\hline From SE & 28.51 & 13.19 & - & 4.91 \\
\hline From SW & 25.39 & 12.03 & 14.84 & - \\
\hline
\end{tabular}

What we can observe from the results is the fact that the impact of internal congestion is of minor importance and the electricity mix stays very close to the single-node model once the two wind power technologies are aggregated. The reason for the replacement of offshore by onshore wind power is the additional flexibility gain thanks to spatial optimization, where more variable but cheap onshore wind replaces more stable but also more expensive offshore wind. The difference in cost is less than 7\% (in line with RTE's 5\% of order of magnitude for a $71 \%$ renewable power system). On the other hand, interconnection inefficiencies lead to $0.9 \%$ of additional loss, and a $15 \%$ increase in load curtailment (from $11.99 \%$ to $14.13 \%$ ), but thanks to the additional flexibility coming from spatial optimization, battery usage - and therefore loss from storage inefficiencies - decreases by $7.3 \%$. 